\title{
2- Yabancı dil olarak Türkçe öğrenenlerin başarılarını etkileyen unsurlar üzerine öğretici görüşleri
}

\section{Ahmet DEMÍREL \\ Çiğdem YALÇIN²}

APA: Demirel, A.; Yalçın, Ç. (2021). Yabancı dil olarak Türkçe öğrenenlerin başarılarını etkileyen unsurlar üzerine öğretici görüşleri. RumeliDE Dil ve Edebiyat Araştırmalarn Dergisi, (Ö10), 22-43. DOI: $10.29000 /$ rumelide.1009035.

$\ddot{O} \mathbf{z}$

Bu araştırmanın amacı öğreticilerin görüşlerinden hareketle yabancı dil olarak Türkçe öğrenenlerin öğrenme başarısında etkin rol oynayan unsurların ortaya çıkarılmasıdır. Bu amaç doğrultusunda yabancı dil olarak Türkçe öğretimine yönelik deneyimi olan öğreticilerin görüşlerine başvurulmuştur. Araştırma nitel araştırma desenlerinden olgubilim desenine uygun bir şekilde yürütülmüştür. Araştırmada yabancı dil olarak Türkçe öğretimi alanında en az bir yıl deneyimi olan sekiz katılımcı yer almıştır. Veriler araştırmacılar tarafindan geliştirilen yarı yapılandırılmış görüşme formu kullanılarak elde edilmiştir. Yarı yapılandırılmış görüşmeler aracılığı ile elde edilen veriler içerik analizi tekniği kullanılarak analiz edilmiştir. Araştırma sonucunda öğreticilere göre yabancı dil olarak Türkçe öğrenenlerin başarısını etkileyen altı temel unsur belirlenmiştir. Bu temel unsurlar; öğrencinin özellikleri, öğreticinin özellikleri, kullanılan materyaller, dilsel benzerlikler, geri bildirimler ve öğrenme ortamlarıdır. Öğreticilere göre Türkçe öğrenenlerin başarısını etkileyen öğrenci özellikleri arasında öğrencinin kişilik özellikleri, birden çok dil bilmesi, eğitim durumu, kendi dilindeki yeterliliği, kültürel donanımı ve uyumu, psikolojisi, teknolojik yeterliliği, tutumu, motivasyonu ve kaygısı, yaşı ve özerkliği yer almaktadır. Türkçe öğrenenlerin başarısını etkileyen öğretici özellikleri arasında ise öğreticinin yaşı, eğitim durumu, alan bilgisi, kişilik özellikleri, kültürel donanımı, pedagojik yeterliliği, psikolojisi, teknolojik yeterliliği, tutumu ve motivasyonu bulunmaktadır. Türkçe öğrenenlerin başarısını etkileyen diğer bir unsur ders kitapları, teknolojik araçlar, etkileşimli kitaplar ve otantik materyaller gibi kullanılan materyallerdir. Alfabe benzerlikleri, dil bilgisel benzerlikler ve sözcük benzerlikleri gibi dilsel benzerlikler de başarıyı etkileyen unsurlar arasında yer almaktadır. Bununla birlikte geri bildirimler de başarıyı etkileyen bir diğer unsur olarak belirlenmiş̧tir. Son olarak öğreticilere göre sosyal çevre, sınıf ortamı ve otantik ortamlar da yabancı dil olarak Türkçe öğrenenlerin başarısını etkilemektedir.

Anahtar kelimeler: Yabancı dil olarak Türkçe, Türkçe öğrenme başarısı, başarıyı etkileyen unsurlar

Arş. Gör. Dr., Nevşehir Hacı Bektaş Veli Üniversitesi, Eğitim Fakültesi, Türkçe ve Sosyal Bilimler Eğitimi Bölümü (Nevşehir, Türkiye), ahmetdemirel@ hotmail.com, ORCID ID: oooo-0003-2249-565X [Araştırma makalesi, Makale kayıt tarihi: 22.09.2021-kabul tarihi: 20.10.2021; DOI: 10.29000/rumelide.1009035]

2 Arş. Gör., Nevşehir Hacı Bektaş Veli Üniversitesi, Eğitim Fakültesi, Türkçe ve Sosyal Bilimler Eğitimi Bölümü (Nevşehir, Türkiye), cigdemm.koc@hotmail.com, ORCID ID: 0000-0002-3051-0920

Adres | Address

RumeliDE Dil ve Edebiyat Araştırmalar Dergisi $\quad$ RumeliDE Journal of Language and Literature Studies Osmanağa Mahallesi, Mürver Çiçeği Sokak, No:14/8 $\quad$ Osmanağa Mahallesi, Mürver Çiçeği Sokak, No:14/8

Kadıköy - ÍSTANBUL / TÜRKIYE 34714 Kadıköy - ISTANBUL / TURKEY 34714 e-posta: editor@rumelide.com e-mail: editor@rumelide.com, tel: +90 505 7958124, +90 2167730616 phone: +90 505 7958124, +90 2167730616 


\title{
The instructors' views on factors affecting the success of learners learning Turkish as a foreign language
}

\begin{abstract}
The aim of this research is to reveal the factors that play an active role in the success of the students learning Turkish as a foreign language, based on the views of the instructors. For this purpose, the views of instructors having experience in teaching Turkish as a foreign language were consulted. The research was carried out in accordance with the phenomenology pattern, one of the qualitative research designs. Eight participants having at least one year of experience in teaching Turkish as a foreign language took part in the research. The data were obtained by using a semi-structured interview form developed by the researchers. The data obtained through semi-structured interviews were analyzed using content analysis technique. As a result of the research, six basic factors affecting the success of learning Turkish as a foreign language were determined according to the instructors. These basic elements are; the characteristics of the learner, the characteristics of the instructor, the materials used, linguistic similarities, feedback and learning environments. According to the instructors, among the student characteristics that affect the success of learning Turkish, there are personality traits, knowledge of multiple languages, educational background, proficiency in his own language, cultural equipment and harmony, psychology, technological competence, attitude, motivation and anxiety, age and autonomy. Among the instructors characteristics that affect the success of learning Turkish are the instructor's age, educational status, field knowledge, personality traits, cultural equipment, pedagogical competence, psychology, technological competence, attitude and motivation. Another factor affecting the success of learning Turkish is the materials used such as textbooks, technological tools, interactive books and authentic materials. Linguistic similarities such as alphabet, grammatical and word similarities are among the factors affecting success. In addition, feedback was also determined as another factor affecting success. Finally, according to the instructors, the social environment, the classroom environment, and authentic environments also affect the success of those who learn Turkish as a foreign language.
\end{abstract}

Keywords: Turkish as a foreign language, Turkish learning success, factors affecting success

\section{Giriş}

Dil insanlar arasındaki iletişimin temel aracıdır. Dil sayesinde insanlar duygu ve düşüncelerini birbirleri ile paylaşabilmekte ve rahat bir biçimde iletişim kurabilmektedir. Değişen dünya düzeninde turizm, ekonomi ve teknoloji gibi alanlarda yaşanan gelişmeler yabancı dil öğretimini ihtiyaç olmaktan çıkararak bir zorunluluk hâline getirmiştir. Dolayısıyla her bireyin bu düzene ayak uydurabilmesi için en az bir yabancı dil bilmesi ve o dilde kendini ifade edebilmesi gerekliliği ortaya çıkmıştır. Yaşanan bu gelişmelerle birlikte her millet kendi dilini öğretmek amacı ile çeşitli girişimlerde bulunmuştur. Çelebi (2006) günümüzde yabancı dil bilmenin çağa yetişmek, onu yakalayabilmek için olmazsa olmaz bir koşut olduğu ifade etmiştir. Yabancı dil öğretimi zorlu ve süreklilik arz eden bir süreçtir. Bu süreçte dil öğrenimi ve öğretiminin niteliğini artırmak dolayısıyla sürecin başarılı bir şekilde tamamlanmasını sağlamak gerekmektedir. Bunun içinse öncelikle dil öğrenenlerin başarısı üzerinde etkili olan unsurların bilinmesi önem arz etmektedir. Geçmişten günümüze yapılan pek çok çalışmada yabancı dil öğretiminde motivasyon, kaygı, tutum, kullanılan materyaller, öğretim yöntemleri gibi birçok unsurun öğrenci başarısını etkilediği belirtilmiştir. Daha önceki çalışmalarda dil öğrenme başarısı üzerinde etkili olduğu ifade edilen başlıca unsurlar aşağıda ele alınmıştır:

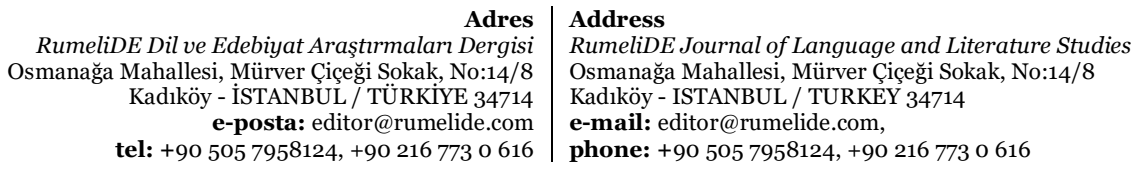


Eğitim öğretim sürecinde hedef kitle son derece önemlidir. Dil öğretiminde de hedef kitle öğretim sürecinin başarısı açısından önem taşımaktadır. Alyılmaz (2018) gerçekleştirdiği çalışmada yabancı dil olarak Türkçe öğretiminde hedef kitlenin önemine değinmiş ve hedef kitlenin yaşının, ana dilinin, cinsiyetinin, zekâ düzeyinin, motivasyonunun, kaygı düzeyinin önemine vurgu yapmıştır. Özer ve Korkmaz (2016) ise gerçekleştirdikleri araştırmada yabancı dil öğretiminde öğrenci başarısını etkileyen unsurları ortaya koymayı amaçlamıştır. Bu araştırmanın bulgularına göre öğretmen ve öğrenci davranışları yabancı dil öğreniminde başarıyı etkileyen etmenlerdir. Bu çalışmalar dil öğretiminde öğrenci ve öğretici özelliklerinin öğrenme başarısında rol oynayan önemli unsurlar olduğunu göstermektedir.

Motivasyon hem öğretmenler hem de araştırmacılar tarafından yabancı dil öğrenim başarısını etkileyen temel faktörlerden biri olan kabul görmüştür (Dörnyei, 1998). Birçok araştırmada motivasyonun dil öğrenme üzerinde etkili bir unsur olduğu ifade edilmiştir (Dörnyei, 1998; Ebata, 2008; Engin, 2009; Mahadi ve Jafari, 2012; Nakata, 2006). Mahadi ve Jafari (2012) yabancı dil olarak İngilizce öğrenenlerin öğrenme başarısını etkileyen unsurları incelemiş ve motivasyonla başarı arasında yüksek oranda ilişki olduğunu tespit etmiştir. Böylece motivasyonun dil öğrenme sürecinde son derece önemli bir unsur olduğunu sonucuna ulaşmışlardır. Tüm bunlar dil öğretiminde motivasyonun önemli bir unsur olduğunu göstermektedir. Bao ve Liu (2021) yabancı dil öğretimini olumlu ve olumsuz etkileyen duyuşsal etmenler üzerine yaptıkları çalışmada öğrencilerin motivasyon ve kaygılarının öğrenmeyi oldukça etkilediğini vurgulamışlardır. Araştırma sonucunda öğrencilerin özgüvenlerini artırmak, kaygılarını azaltmak, motivasyonlarını ve öğrenme verimliliklerini artırmak için öğreticilerin pedagojik, psikolojik ve metodolojik bilgiyle donatılmaları gerektiğini belirtmişlerdir. Benzer şekilde Ni (2012) ikinci dil öğretiminde pedagojik etkiler ve duyuşsal unsurlar üzerine yaptığı çalışmada özellikle motivasyon, öz güven ve kaygı gibi duyuşsal unsurların önemine vurgu yaparak bu unsurları göz önünde bulundurmanın öğretmenlerin öğretim kalitesini geliştirmelerine ve öğrencilerin de kendilerini çok yönlü yetiştirmelerine yardımcı olacağını belirtmiştir.

Kültür dil öğretiminde etkili olduğu belirtilen bir diğer unsur olarak karşımıza çıkmaktadır. Birçok araştırmada dil öğretiminde kültürel unsurların önemine vurgu yapılmıştır (Byram ve Feng, 2004; Çakır, 2011; Sarıçoban ve Çalışkan, 2011). Türkoğlu (2004) kültürel etmenleri dil öğretiminde öğrenci başarısını etkileyen başlıca etmenlerden biri olarak ele almış ve bir yabancı dilin öğrenilmesinde kültürel ve sosyal etmenlerin oldukça önemli bir yer tuttuğunu ifade etmiştir. Çakır (2011) kültürün yabancı dil öğretiminde dilden ayrı tutulan bir unsur olarak görülmemesi gerektiğini, onun yabancı dil öğretiminin bir parçası olduğunu ifade etmiştir. Er (2006) ise yabancı dil öğretiminde öğretilen dilin kültürel özelliklerinin öğrencilere aktarılmasının önemli olduğunu ifade etmiştir. Bir yabancı dil öğretilirken hedef kültürün de öğretilmesi öğrencilerin daha iyi öğrenmesini sağlayacaktır (Alpar, 2013). Dolayısıyla yabancı dil öğretiminde kültüründe öğretilmesine önem verilmeli ve dil öğretiminde kültürün önemli bir unsur olduğu unutulmamalıdır.

Benimsenen öğretim yöntemleri yabancı dil öğretiminde başarı üzerinde etkili olan bir diğer unsur olarak karşımıza çıkmaktadır. Yapılan araştırmalarda öğretim yönteminin öğrenme başarısı açısından önemli olduğu ifade edilmiştir (Nguyen, Warren ve Fehring, 2014; Türkoğlu, 2004). Nguyen, Warren ve Fehring (2014) yapmış oldukları çalışmada lisede İngilizce öğrenimini ve öğretimini etkileyen unsurları araştırmışlar ve öğreticilerin uygun metot ve yöntemleri seçememelerinin, zamanı etkili kullanamamalarının, sınıf yönetimindeki eksikliklerinin, teknoloji ve materyalleri sınırlı şekilde kullanmalarının dil öğretiminin kalitesini etkilediğini savunmuşlardır. Bununla birlikte Özer ve Korkmaz (2016) yabancı dil öğretiminde öğrenci başarısı üzerinde öğretmenin, ders işlenişinin ve

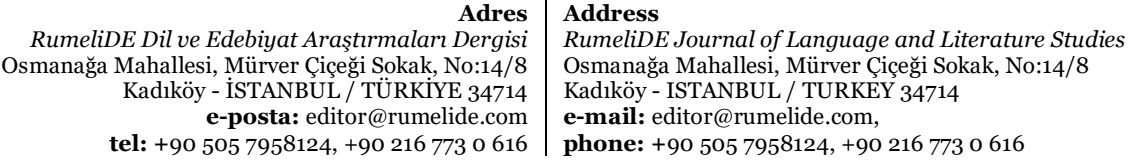


çevrenin etkisine değinmiştir. Ayrıca Türkoğlu (2004) yabancı dil öğretiminde başarıyı etkileyen etmenlerden birinin dil öğretim yöntemleri olduğunu belirtmiştir. Bu çalışmalardan yola çıkıldığında genelde dil öğretiminde özelde ise yabancı dil öğretiminde başarıyı etkilen bilişsel, duyuşsal ve sosyal birçok unsur olduğu söylenebilir.

\section{Araştırmanın amacı}

Yabancı dil öğretiminde başarıyı etkileyen motivasyon, kültürel farkındalık, öğretmen tarafından benimsenen öğretim yöntemi gibi birçok unsur bulunmaktadır (bk. Alyılmaz , 2018; Çakır, 2011; Ni, 2012). Bunların dışında yapılan çalışmalarda öğrenme biçemleri (Gezmiş ve Sarıçoban, 2005), ölçme ve değerlendirme uygulamaları (Altmışdört, 2010), sosyal çevre (Alsayed, 2003), alfabe benzerlikleri (Şengül, 2014) gibi birçok unsurun yabancı dil öğretiminde başarı açısından önemli olduğu ifade edilmiştir. Ancak yabancı dil olarak Türkçe öğretiminde öğreticilerin gözüyle Türkçe öğrenenlerin başarısını etkileyen temel unsurların ortaya konduğu herhangi bir çalışmaya rastlanmamıştır. $\mathrm{Bu}$ araştırmada amaç yabancı dil olarak Türkçe öğrenenlerin başarısında etkili olan unsurları öğreticilerin görüşlerinden hareketle ortaya çıkarmaktır. Araştırmada yabancı dil olarak Türkçe öğrenenlerin başarısı üzerinde etkili olan unsurların belirlenmesi amacı ile öğreticilerinin deneyimlerine başvurulmuştur.

\section{Yöntem}

\section{Araştırma deseni}

$\mathrm{Bu}$ araştırma nitel araştırma desenlerinden olgubilim desenine uygun bir şekilde gerçekleştirilmiştir. Olgubilim (fenomenoloji) çalışmaları farkında olduğumuz ancak derinlemesine ve ayrıntılı bir anlayışa sahip olmadığımız olgulara odaklanarak yaşantıları ve anlamları ortaya çıarmaya yöneliktir (Yıldırım ve Şimşek, 2018). Bu araştırmada yabancı dil olarak Türkçe öğrenenlerin başarılarını etkileyen unsurların öğreticilerin deneyimlerinden hareketle ortaya çıkarılması amaçlandığından olgubilim desenine başvurulmuştur.

\section{Katılımcilar}

$\mathrm{Bu}$ araştırmada katılımcıların belirlenmesinde yabancı dil olarak Türkçe öğretimi alanında deneyimli olma durumu dikkate alınmıştır. Bu nedenle katılımcılar belirlenirken katılımcıların en az bir yll yabancı dil olarak Türkçe öğretimi deneyimine sahip olmalarına dikkat edilmiş ve bu doğrultuda deneyim şartını sağlayan sekiz öğretici katılımcı olarak yer almıştır. Katılımcılara ilişkin demografik bilgiler aşağıdaki gibidir:

Tablo 1: Katılımcılara ilişkin demografik bilgiler

\begin{tabular}{ll}
\hline Katılımcılar & \\
\hline \multirow{2}{*}{ Cinsiyet } & 6 Kadın \\
\cline { 2 - 2 } & 2 Erkek \\
\hline Yaş & $27-36$ yaş arası \\
\hline Mesleki Deneyim & $1-7$ yl arası \\
\hline
\end{tabular}

\footnotetext{
Adres | Address

RumeliDE Dil ve Edebiyat Araştırmaları Dergisi Osmanağa Mahallesi, Mürver Çiçeği Sokak, No:14/8 Kadıköy - ÍSTANBUL / TÜRKIYE 34714 e-posta: editor@rumelide.com tel: +90 $5057958124,+902167730616$

RumeliDE Journal of Language and Literature Studies

Osmanağa Mahallesi, Mürver Çiçeği Sokak, No:14/8

Kadıköy - ISTANBUL / TURKEY 34714

e-mail: editor@rumelide.com,

phone: +90 $5057958124,+902167730616$
} 


\section{Veri toplama araçları}

Araştırmada veri toplama aracı olarak araştırmacılar tarafından geliştirilen yarı yapılandırılmış görüşme formu kullanılmıştır. Yarı yapılandırılmış görüşme formunda öğreticilerin yabancı dil olarak Türkçe öğrenenlerin başarılarını etkileyen unsurlar hakkındaki görüşlerine yönelik beş açık uçlu soru bulunmaktadır. Yarı yapılandırılmış görüşme formunun ilk taslağı yapılan alayazın taraması sonucunda oluşturulmuştur. Taslak formun geçerliği için üç alan uzmanının görüşüne başvurulmuş ve bu uzman görüşleri doğrultusunda forma son hâli verilmiştir. Görüşme formunun güvenirliği için ise form yabancı dil olarak Türkçe öğreten beş öğreticiye gönderilerek sorulara verilen cevapların tutarlılığ 1 iki alan uzmanı tarafından incelenmiştir. Alınan yanıtların tutarlı olduğu görülmüşsür. Yarı yapılandırılmış görüşmeler, araştırmacıların bir ilgi alanında hem sabit seçenekli yanıtlar hem de derinlemesine bilgi almalarına olanak tanımaktadır (Büyüköztürk, Kılıç Çakmak, Akgün, Karadeniz ve Demirel, 2016).

\section{Verilerin analizi}

Verilerin analizinde MAXQDA 20 nitel veri analizi programı kullanılmıştır. Katılımcılarla yapılan görüşmelerle elde edilen veriler MAXQDA 20 nitel veri analizi programına aktarılmış ve bu program üzerinden verilerin analizi içerik analizi tekniğine uygun bir biçimde gerçekleştirilmiştir. Verilerin analizi esnasında kodlamalar iki farklı kodlayıcı tarafından yapılmıştır. Süreç sonunda ise iki farklı kodlayıcının yaptığı kodlamalar için kodlayıcılar arası uyum hesaplanmıştır. Kodlayıcılar arası uyumun hesaplanmasında Miles ve Huberman (1994) tarafından önerilen formül kullanılmıştır. Sonuç olarak kodlayıcılar arası uyumun .86 olduğu görülmüştür. Miles, Huberman ve Saldana (2014) kod şemasının boyutuna ve aralığına bağlı olarak kodlayıcılar arası uyumun .85 ile .90 aralığında olması gerektiğini belirtmektedir. Dolayısıyla çalışmada yeterli düzeyde kodlayıcılar arası uyum sağlandığı söylenebilir.

\section{Etik kurallara uygunluk}

Bu çalışmada "Yükseköğretim Kurumları Bilimsel Araştırma ve Yayın Etiği Yönergesi” kapsamında uyulması belirtilen tüm kurallara uyulmuştur. Nevşehir Hacı Bektaş Veli Üniversitesi Bilimsel Araştırmalar ve Yayın Etik Kurulu tarafından 14.06.2021 tarihi ve 232 sayısı ile araştırmanın gerçekleştirilmesine yönelik etik sakınca bulunmadığına karar verilmiştir.

\section{Bulgular ve yorum}

Öğreticilerle yapılan görüşmeler sonucunda yabancı dil olarak Türkçe öğrenme başarısını etkileyen altı temel unsur belirlenmiştir. Bunlar; öğrencinin özellikleri, öğreticinin özellikleri, kullanılan materyaller, dilsel benzerlikler, geri bildirimler ve öğrenme ortamlarıdır. Aşağıda bu temel unsurlar ve bu unsurlar altında yer alan alt unsurlar tek tek ele alınmış ve katılımcılardan alınan doğrudan alıntılara yer verilmiştir.

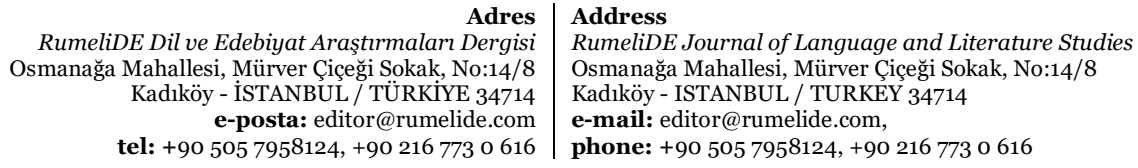




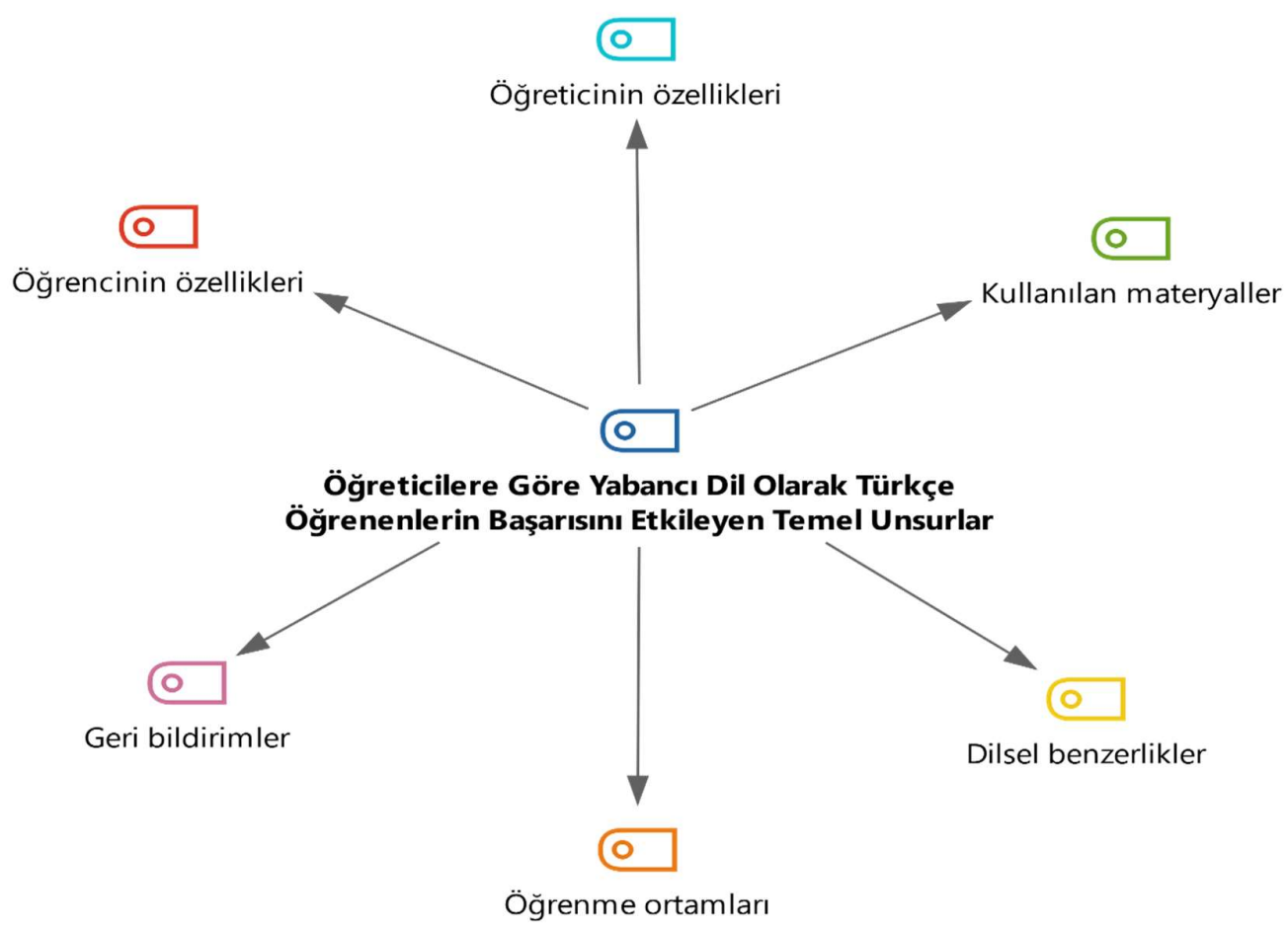

Şekil 1: Katılımcılara göre yabancı dil olarak Türkçe öğrenenlerin başarısını etkileyen temel unsurlar

Şekil 1'de görüldüğü gibi öğreticilere göre öğrencinin özellikleri, öğreticinin özellikleri, kullanılan materyaller, dilsel benzerlikler, geri bildirimler ve öğrenme ortamları yabancı dil olarak Türkçe öğrenenlerin başarısını etkileyen temel unsurlardır. Aşağıda bu unsurlar tek tek ele alınmış ve bu unsurlar hakkındaki öğretici görüşlerinden örneklere yer verilmiştir.

\section{Öğrencinin özellikleri}

Katılımcılara göre yabancı dil olarak Türkçe öğrenenlerin başarısında etkili olan temel unsurlardan biri öğrenci özellikleridir. Katılımcılar öğrenci özelliklerinin Türkçe öğrenme başarısını etkileyen temel unsurlardan biri olduğunu ifade etmiştir. Aşağıda Türkçe öğrenme başarısı üzerinde etkili olduğu ifade edilen öğrenci özelliklerine yer verilmiştir.

RumeliDE Dil ve Edebiyat Araşttrmaları Dergisi Osmanağa Mahallesi, Mürver Çiçeği Sokak, No:14/8 Kadıköy - İSTANBUL / TÜRKIYE 34714 e-posta: editor@rumelide.com tel: +90 $5057958124,+902167730616$
Address

RumeliDE Journal of Language and Literature Studies Osmanağa Mahallesi, Mürver Çiçeği Sokak, No:14/8

Kadıköy - ISTANBUL / TURKEY 34714

e-mail: editor@rumelide.com,

phone: +90 5057958124, +90 2167730616 
The instructors' views on factors affecting the success of learners learning Turkish as a foreign language / A. Demirel; Ç. Yalçın (pp. 22-43)

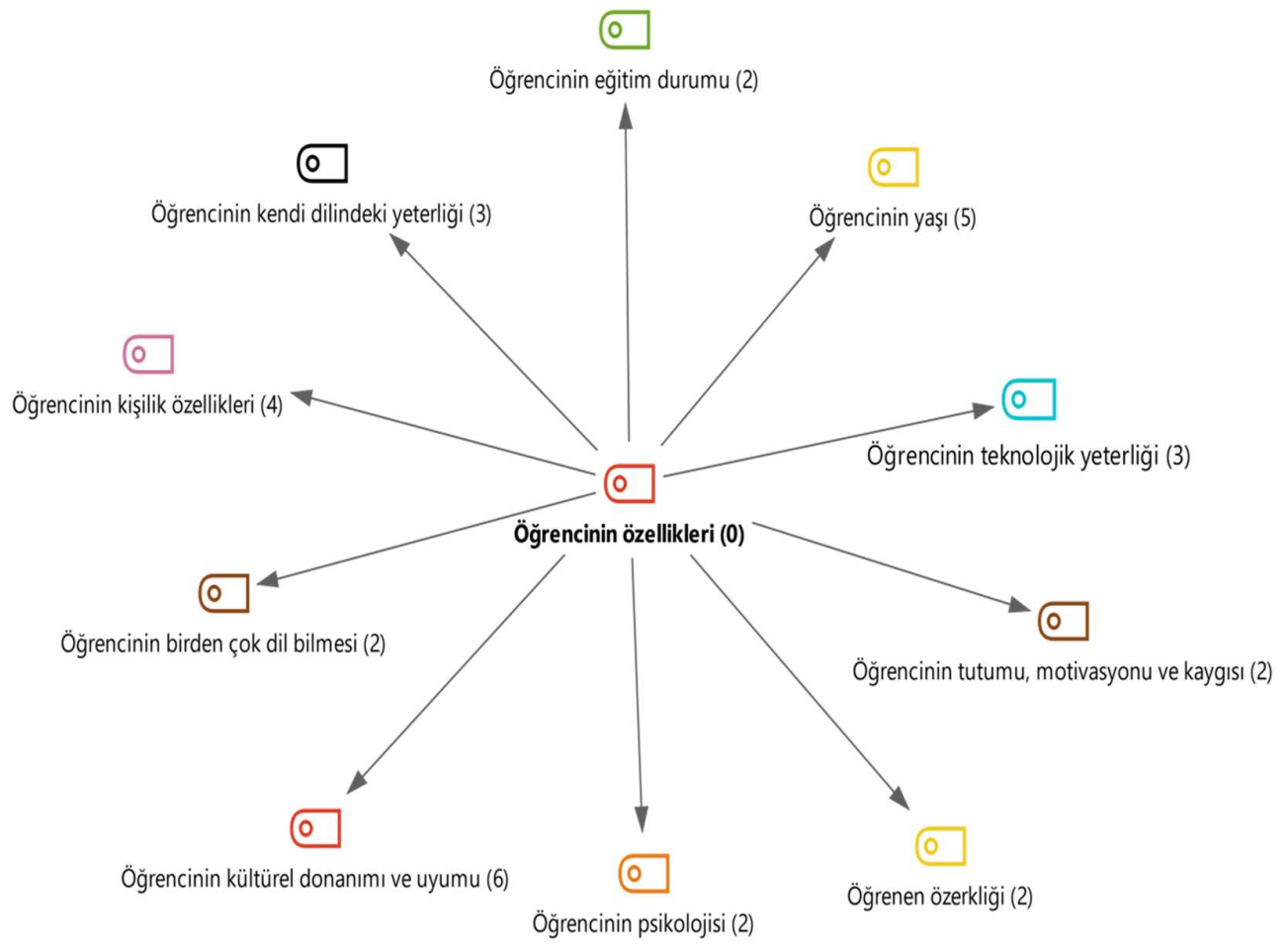

Şekil 2: Katılımcılara göre Türkçe öğrenme başarısı üzerinde etkili olan öğrenci özellikleri

Katılımcılar öğrencinin eğitim durumunun ( $f=2)$, yaşının $(f=5)$, teknolojik yeterliğinin $(f=3)$, öğrenen özerkliğinin ( $f=2)$, birden çok dil bilmesinin ( $f=2)$, kültürel donanımı ve uyumunun ( $f=6$ ), psikolojisinin $(\mathrm{f}=2)$, kendi dilindeki yeterliği $(\mathrm{f}=2)$ ve kişilik özelliklerinin $(\mathrm{f}=4)$ Türkçe öğrenme başarısı üzerinde etkili olduğunu ifade etmişlerdir. Bununla birlikte katılımcllara göre öğrencinin öğrenme tutumu, motivasyonu ve kaygısı ( $\mathrm{f}=2$ ) da öğrenme başarısı üzerinde etkilidir. Aşağıda Türkçe öğrenme başarısına etki ettiği ifade edilen bu özellikler tek tek ele alınmıştır.

Ĕ̆itim durumu: Katılımcılardan bazıları öğrencinin eğitimi durumunun Türkçe öğrenme başarısı üzerinde etkili olduğunu ifade etmiştir. Onlara göre eğitim seviyesi yüksek olan öğrenciler daha başarılı olabilmektedir. Aşağıda katılımcıların bu duruma ilişkin ifadelerinden biri örnek olarak verilmiştir:

"Eğitim durumu şöyle önemli yani hiç okuryazar olmayan öğrencilerimiz vardı bir kere kendi dilinde okuryazar değil. Şimdi siz üniversite bitirmiş birkaç dil bilen bir insana yeni bir dil öğretirken hiç bilmeyene kıyasla oldukça farkh durumlar ortaya çıkar. Belki benim söylediğim çok uç noktalar ama siz bunu indirgeyebilirsiniz. Ama makas kapandıkça bu farkın da azaldığını söyleyebiliriz. Yani buradaki en önemli nokta öğrencinin kendi dilinde okuryazar olup olmamasl ile ilgili. Kendi dilinde okuryazar değilse maalesef çok ama çok zorlanıorsunuz. Çünkü sizin önce öğrenciye okuma yazma öğretmeniz gerekiyor.” (K4)

Yaşı: Katılımcılara göre Türkçe öğrenme başarısı üzerinde etkili olan bir diğer unsur öğrencinin yaşıdır. Katılımcılardan bazıları öğrenci yaşının çok büyük veya çok küçük olmasının öğrenme başarısını olumsuz etkileyebileceğini ifade etmiştir. Aşağıda katılımcıların bu duruma ilişkin ifadelerinden biri örnek olarak verilmiştir:

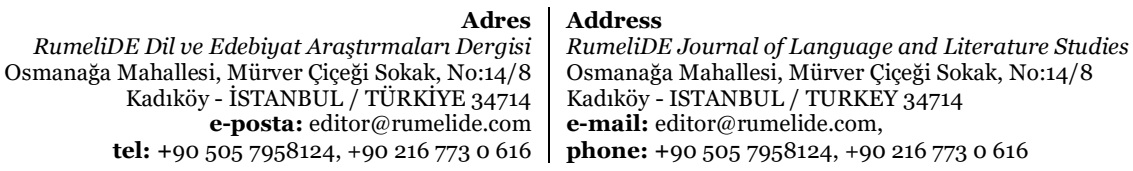


“Öğrencinin yaşı en önemli özellik. TÖMER’de siz yetişkinlere direkt Türkçe öğretiyorsunuz ama çocuklara önce sinff yönetimi uyguluyorsunuz. Yaş düştükçe zorluk artıyor. 40 yaş üstü bize gelen öğrenciler özellikle ciddi bir eğitim almamışlarsa ciddi anlamda bir zorluk yaşanıyor.”(K4)

Teknolojik yeterliği: Katılımcılara göre Türkçe öğrenme başarısına etki eden unsurlardan biri öğrencinin teknolojik yeterliğidir. Katılımcılara göre teknolojik yeterliği yüksek olan öğrenciler daha başarılı olabilmektedir. Aşağıda katılımcıların bu duruma ilişkin ifadelerinden biri örnek olarak verilmiştir:

"Teknolojik yeterliği yüksek öğrenciye mesela sunum yaptırıyorum ve sunum yapmada daha başarılı oluyor. Sunum istiyorum word programına yazıp getiriyor. Bazllar power point kullanıyor arkasına müzik ekliyor bunları yapmaktan hoşlanıyor çünkü ilgisi var. Yani yüz yüze eğitimde öğrencinin teknolojiyi kullanabilmesi başarısını olumlu yönde etkiliyor.” (K2)

Tutumu, motivasyonu ve kaygısı: Katılımcılara göre Türkçe öğrenme başarısına etki eden unsurlardan biri öğrencinin öğrenmeye yönelik tutumu, kaygısı ve motivasyonudur. Katılımcılardan bazıları öğrenme motivasyonu yüksek olan, olumlu tutuma sahip olan öğrencilerin daha başarılı olduğunu ifade etmiştir. Ayrıca katılımcılara göre öğrenme kaygısının çok az ya da çok fazla olması öğrenme başarısını olumsuz etkileyebilmektedir. Aşağıda katılımcıların bu duruma ilişkin ifadelerinden biri örnek olarak verilmiştir:

"Olumsuz bir tutum geliştirdiyse veya Türkçe öğrenmeye ilişkin bir motivasyonu yoksa öğretmekte zorlanıyorsunuz. Çünkü ödev yapmıyor, derse gelmiyor, hiçbir şeye katılmıyor. Mesela üniversiteye YÖS ile yerleşen biri burada üniversite okuma motivasyonuna sahipse daha iyi dersleri takip ediyor. Bazen burslu öğrencilerimiz oluyor onlarında burs kesilir kaygısı var ama ben bu kaygının çok ciddi olmadığın düşünüyorum. Hatta olumlu bir tarafi olduğunu düşünüyorum. Ama tabii kaygı çok fazla olmamah düşük oranda olduğunda faydah olduğunu düşünüyorum. Çocuk eğer sinffa babasının ve annesinin zoruyla değil de kendi isteğiyle yani kendi içsel motivasyonu ile katıldıysa bu dersteki başarısını doğrudan etkileyen bir faktör oluyor.” (K1)

Öğrenen özerkliği: Katılımcılara göre yabancı dil olarak Türkçe öğrenenlerin başarısı üzerinde etkili olan unsurlardan bir diğeri de öğrenen özerkliğidir. Katılımcılardan bazıları öğrenen özerkliği yüksek olan öğrencilerin daha başarılı olabildiğini ifade etmiştir. Katılımcıların bu duruma ilişkin ifadelerinden bazıları şunlardır:

“Özerk öğrenen bir öğrenciyse yani nasll öğreneceğinin farkında olan biriyse, hangi öğrenme metotlarının kendisinin öğrenmelerini kolaylaştırdığının farkındaysa bu da dil öğretiminde çocuğu başarlya götürür. Şöyle düşünün iki öğrencimiz var ikisinin de motivasyonu çok yüksek ama biri nasıl çalışacağının farkında diğeri ise hiçbir şekilde bu noktada bir bilince sahip değil sürekli birilerinden, öğretmeninden, ailesinden bir yönlendirilme ihtiyacı hissediyor. İşte bu belirsizlik yaşayacaktır. Ama özerk öğrenen birey her zaman daha kolay başarıya ulaşıyor.”(K1)

Psikolojisi: Katılımcılara göre yabancı dil olarak Türkçe öğrenenlerin başarısı üzerinde etkili olan unsurlardan biri de öğrencinin içerisinde bulunduğu psikolojik durumdur. Katılımcılardan bazıları psikolojik olarak iyi durumda olan öğrencilerin daha başarılı olduğunu ifade etmiştir. Katılımcıların bu duruma ilişkin ifadelerinden biri şu şekildedir:

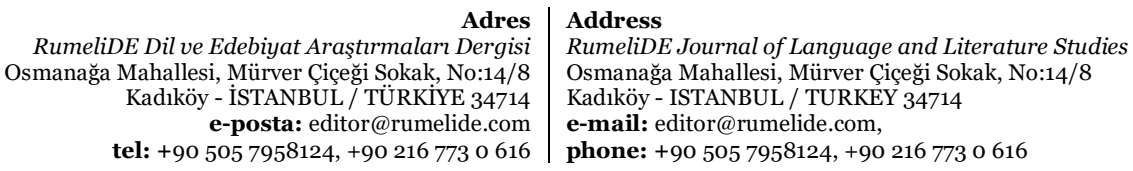


The instructors' views on factors affecting the success of learners learning Turkish as a foreign language / A. Demirel; Ç. Yalçın (pp. 22-43)

“Öğrencinin psikolojisi başarıyı etkiliyor. Mesela öğrenci Suriye’den gelmiş annesini, babasını kaybetmiş ve Türkiye'de hayata tutunmaya çalışıyor. Okuma metninde aile teması işleniyor. Öğrenci etkinliğe katılmak istemiyor. Burada öğreticiye çok iş düşüyor. Öğretici bu gibi etkenleri göz önünde

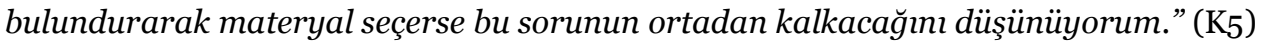

Kültürel donanımı ve uyumu: Katılımcılara göre yabancı dil olarak Türkçe öğrenenlerin başarısı üzerinde etkili olan unsurlardan biri öğrencinin kültürel donanımı ve uyumudur. Katılımcılardan bazıları kültürel donanımı ve uyumu yüksek olan öğrencilerin Türkçe öğrenme başarılarının daha yüksek olduğunu ifade etmiştir. Katılımcıların bu duruma ilişkin ifadelerinden bazıları şunlardır:

“Öğrencinin kültürel donanımını başarı üzerinde etkili olduğunu düşünüyorum. Erasmus öğrencilerine ders verdiğimde hepsi Avrupa'dan gelmiş öğrencilerdi. Normalde bizim öğrencilerimiz daha çok Suriye'den ve Somali'den geliyor. Kullandiğını Türk kültürüne ait metinler öğrencilerin zaten aşina olduğu konularda. Mesela bir bayram metni ya da camileri vs. anlatılan bir metin bu nedenle etkili olduğunu düşünüyorum. Farkh kültürleri biliyor olması da yani kültürlerarası beceriye sahip olması da tabii ki başar üzerinde etkili. Özellikle Türk kültürüne ki tabi ki bu becerisini geliştirdiyse konuyu daha iyi anlayabiliyor. Ama bilmeyen için bu çok absürt bir durum olabiliyor." (K8)

Birden çok dil bilmesi: Katılımcılara göre yabancı dil olarak Türkçe öğrenenlerin başarısı üzerinde etkili olan unsurlardan biri öğrencinin birden çok dil bilme durumudur. Katılımcılardan bazıları birden çok dil bilen öğrencilerin Türkçe öğrenme noktasında daha başarılı olduğunu ifade etmiştir. Katılımcıların bu duruma ilişkin ifadelerinden bazıları şunlardır:

“Örneğin öğrencinin ana dili söz dizimi bağlamında Türkçeye hiç benzemiyor. Ama Türkçeye benzer yapıda farklı bir dil öğrenmiş. Bu nedenle onun Türkçe öğrenirken zorlanmayacağımı, daha başarılı olacağını düşünüyorum.”(K5)

Kişilik özellikleri: Katılımcılara göre yabancı dil olarak Türkçe öğrenenlerin başarısı üzerinde etkili olan unsurlardan biri öğrencinin kişilik özellikleridir. Katılımcılardan bazıları içine kapanık öğrencilerin Türkçe öğrenme başarısının düşük olduğunu, sosyal becerileri yüksek olan öğrencilerin ise Türkçe öğrenme başarısının daha yüksek olduğunu ifade etmiştir. Aşağıda katılımcıların bu duruma ilişkin ifadelerinden biri örnek olarak verilmiştir:

"Kimisi çok aktif ve dil öğretim sürecine çok aktif bir şekilde katılyyor, sosyal becerileri gelişmiş dolayısıyla her türlü etkinliğe katılıyor ve çok daha hızh ilerliyor. Ama hiçbir şekilde konuşturamadığımız öğrenciler var. Daha içine kapanık, sosyal becerileri gelişmemiş. Bunlar tepkide gösteriyor, istemiyorlar katılmayı. Dolayısıyla bu öğrenciler yavaş bir gelişim gösteriyor ve böyle öğrencilere Türkçe öğretmek daha zorlaşıyor.” (K7)

Kendi dilindeki yeterliği: Katılımcılara göre yabancı dil olarak Türkçe öğrenenlerin başarısı üzerinde etkili olan unsurlardan biri de öğrencinin ana dilindeki yeterliğidir. Katılımcılardan bazıları ana dilindeki yeterliği yüksek olan öğrencilerin daha başarılı olduğunu ifade etmiştir. Aşağıda katılımcıların bu duruma ilişkin ifadelerinden biri örnek olarak verilmiştir:

"Maalesef öğrencinin ana dilinde yetersiz oluşu yeni bir dil öğrenirken onu olumsuz etkiliyor. Dolayısıyla öğrenci başarısız oluyor. Örneğin hadi bana bir fiil söyle dediğimde çocuk daha fiilin ne olduğunu bilmiyor. Hadi fiil sıfat kolay ama öğrenci kendi dilinde zarfin ne olduğunu bilmiyor. Kendi

Adres | Address

RumeliDE Dil ve Edebiyat Araştırmalar Dergisi $\quad$ RumeliDE Journal of Language and Literature Studies Osmanağa Mahallesi, Mürver Çiçeği Sokkak, No:14/8 $\quad$ Osmanağa Mahallesi, Mürver Çiçeği Sokak, No:14/8 Kadıköy - İSTANBUL / TÜRKIYE 34714 Kadıköy - ISTANBUL / TURKEY 34714 e-posta: editor@rumelide.com e-mail: editor@rumelide.com, tel: +90 505 7958124, +90 2167730616 phone: +90 505 7958124, +90 2167730616 
dilinde zarfin ne olduğunu bilmiyorsa B düzeyinde zarfı nasıl öğreteceğim? Ya da evet arkadaşlar şimdi fiilden isim yapmayı öğreniyoruz şimdi senin sigara içmenden hoşlanmıyorum dediğimde oradaki-me eki ile isim yaptım dediğimde oradaki ek Farsça, Arapçada yani kendi dilinde buna vakıf değil. O yüzden başarı için kendi dilinde yeterli olmah.”(K2)

\section{Ö̆̆greticinin özellikleri}

Katılımcılara göre yabancı dil olarak Türkçe öğrenenlerin başarısında etkili olan temel unsurlardan biri de öğreticidir. Aşağıda Türkçe öğrenme başarısı üzerinde etkili olduğu ifade edilen öğretici özelliklerine yer verilmiştir:

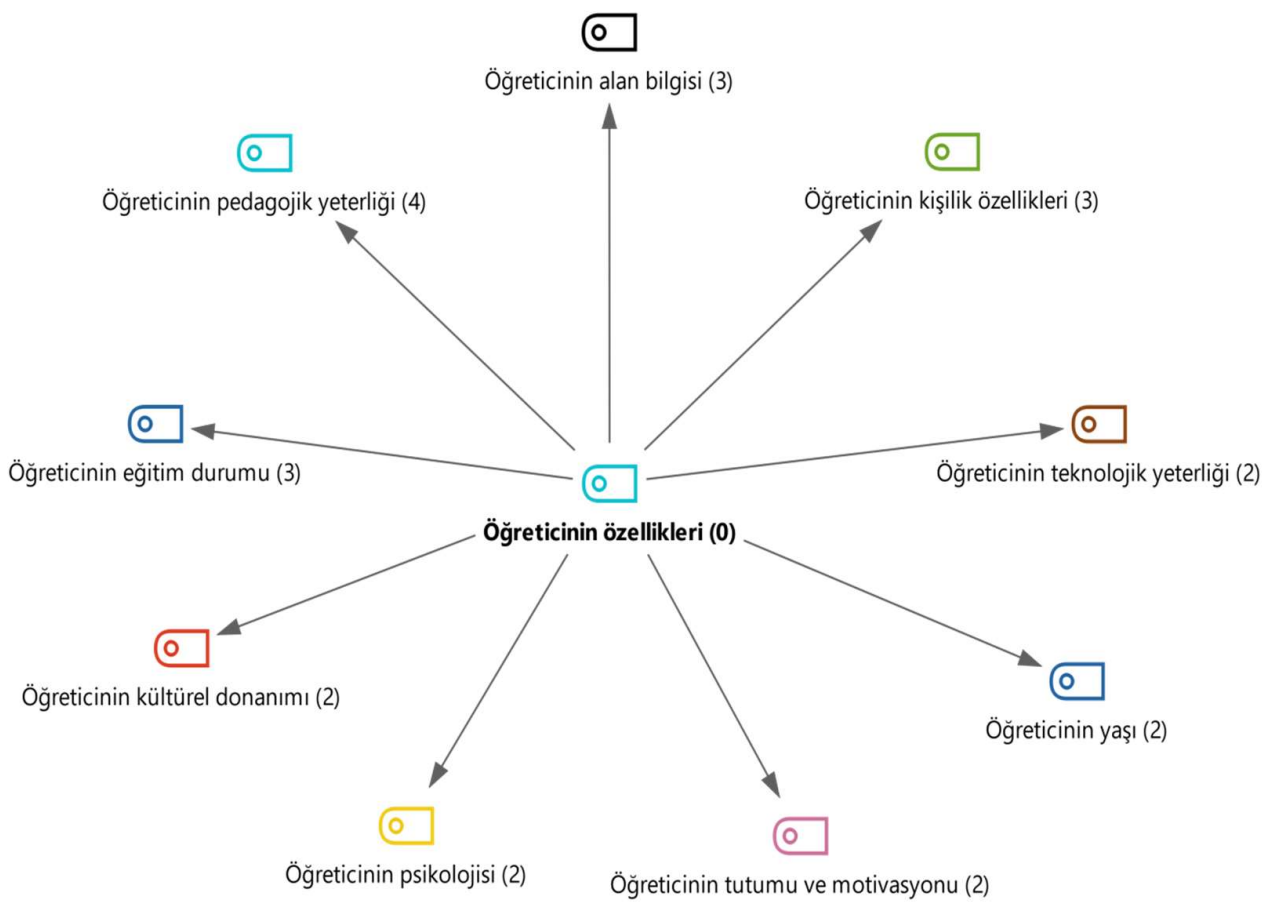

Şekil 3: Katılımcılara göre Türkçe öğrenme başarısı üzerinde etkili olan öğretici özellikleri

Şekil 3’te görüldüğü gibi katılımcllara göre öğreticinin alan bilgisi ( $\mathrm{f}=3$ ), kişilik özellikleri ( $\mathrm{f}=3$ ), teknolojik yeterliliği $(\mathrm{f}=2)$, yaşı $(\mathrm{f}=2)$, tutumu ve motivasyonu $(\mathrm{f}=2)$, psikolojisi $(\mathrm{f}=2)$, kültürel donanımı $(\mathrm{f}=2)$, eğitim durumu $(\mathrm{f}=3)$, pedagojik yeterliğ $(\mathrm{f}=4)$ Türkçe öğrenme başarını etkilemektedir. Aşağıda Türkçe öğrenme başarısı üzerinde etkili olduğu ifade edilen bu unsurlar tek tek ele alınmıştır:

Alan bilgisi: Katılımcılara göre yabancı dil olarak Türkçe öğrenenlerin başarısı üzerinde etkili olan unsurlardan biri öğreticinin alan bilgisidir. Katılımcllar Türkçe alan bilgisi yüksek olan öğreticilerin Türkçe öğrenme başarısını artırdığını ifade etmişlerdir. Aşağıda bu duruma ilişkin bir katılımcı ifadesi örneğine yer verilmiştir:

“Öğretmenin sahip olması gereken özellikler var. Birincisi Türk dilinin inceliklerini bilmesi gerekiyor. Türkçenin kurallarını, kaidelerini, özelliklerini, farkh örneklerde ortaya çlkan durumlarmı çok iyi bilmeli. Her birini öğrenci soruyor derste. Bunlara cevap verebilecek nitelikte olması lazım. Başarı için önemli bir durum bu." (K1)

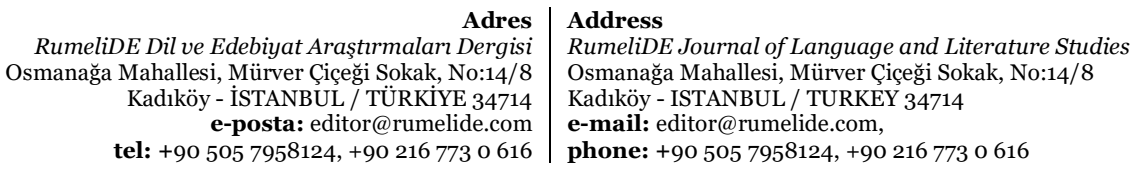


Kişilik özellikleri: Katılımcılara göre yabancı dil olarak Türkçe öğrenenlerin başarısı üzerinde etkili olan unsurlardan biri öğreticinin kişilik özelliklerdir. Katılımcılar dışa dönük, sosyal becerileri yüksek olan öğreticilerin öğrenenlerin Türkçe öğrenme başarısını artırabildiğini ifade etmişlerdir. Katılımcıların bu duruma ilişkin ifadelerinden bir örnek şu şekildedir: “Öğreticinin kişilik özellikleri başarıda çok önemli özellikle bilgi birikimi fazla hocalarmız var ama hoplayıp zıplamak, şarkı söylemek, eğlenmek vs. bu tür şeyleri yapamıyor. Kişilik özelliklerinde bu yok, içe kapanıklar. Dolayısıyla bunu yapabilen öğreticiler için bu durum daha olumlu neticeler doğuruyor.”(K4)

Teknolojik yeterlĭgi: Katılımcılara göre yabancı dil olarak Türkçe öğrenenlerin başarısı üzerinde etkili olan unsurlardan biri de öğreticinin teknolojik yeterliğidir. Katılımcllar teknolojik yeterliği yüksek olan öğreticilerin öğrenenlerin Türkçe öğrenme başarısını artırabildiğini ifade etmişlerdir. Aşağıda bu duruma ilişkin bir katılımcı ifadesi örneğine yer verilmiştir:

"Teknolojik materyaller denince sadece online eğitim akla geliyor. Ama tam tersi biz bu materyalleri yüz yüze daha aktif kullanıyoruz. Bu tür materyaller öğrencilere daha cazip geliyor. Hem eğlenceli oluyor hem de bunu bir uygulama olarak kullanyorsa aktif olarak ders sonrasinda da kullanabiliyor. Biliyorsunuz Kahoot çok meşhur şu aralar. Şimdi biz de Quizlet diye bir şey kullanıoruz. Orada kelimeler var mesela bu bir kelime programı. İçine kelimeleri yüklüyoruz. Öğrenciler bunu hem evlerinde hem de kendi aralarında oynayabiliyorlar. Bu hem iletişimi çok güçlendiriyor hem öğrenmelerini güçlendiriyor. Dolayısıyla öğreticinin teknolojik yeterliği başarıda önemli bir etken.” $\left(\mathrm{K}_{3}\right)$

Yaşı: Katılımcılara göre yabancı dil olarak Türkçe öğrenenlerin başarısı üzerinde etkili olan unsurlardan bir diğeri ise öğreticinin yaşıdır. Katılımcılardan bazıları öğreticinin yaşının başarı üzerinde etkili olabildiğini dile getirmişlerdir. Aşağıda bu duruma ilişkin bir katılımcı ifadesine yer verilmiştir.

“Öğreticinin yaşı çok genç olursa ciddi bir problem öte yandan çok yaşh olmaları da sorun olabiliyor. Onlar daha hassas davranıyorlar hatta daha şahsileştiriyorlar sınff ortamında olanları. İdeal yaş arah̆̆ı bence 26 ve üzeri. 23 yaşında öğreticiler çok öz güveni yüksek bile olsa en ufak bir şeyde kurllıyor üzülüyor vs. O yüzden öğretici ve öğrencinin yaşı öğrenmeyi oldukça etkiliyor.” (K3)

Tutumu ve motivasyonu: Katılımcılara göre yabancı dil olarak Türkçe öğrenenlerin başarısı üzerinde etkili olan unsurlardan bir diğeri de öğreticinin tutumu ve motivasyonudur. Katılımcllar öğreticinin öğrencilerine yönelik tutumu ile öğretmeye yönelik motivasyonunun onların öğrenme başarısı üzerinde etkili olduğunu ifade etmişlerdir. Onlara göre motivasyonu yüksek olan ve öğrencilerine yönelik olumlu tutum sergileyen öğreticiler Türkçe öğrenme başarısını olumlu etkilemektedir. Aşă̆ıda bu duruma ilişkin bir katılımcı ifadesine örnek olarak yer verilmiştir:

"Farklı milletlerden gelen öğrenciler var ya da aynı milletten oldukların düşünelim. Herkesin belli bir hassasiyeti var. Bazen kitaplarda çlkan bir kelime bir cümle ya da bir fotoğraf çok farkh şeylere sebep olabiliyor. Bir öğrenci bunlara tepki veriyor, diğeri onu savunuyor. Mesela öğretmen tahtaya yazı yazıyor öğrenci el işaretiyle çekilmesini istiyor ya da emir kipiyle çekil diyor. Bu bize göre kaba bir ifade çünkü öğrenci emir cümlesi kullanıyor. Ĕger hoca bunu şahsileştirirse ve bu kişi bu dili yeni öğreniyor daha bilmiyor nasıl ifade edileceğini diye düşünmezse bir çatışma çıkıyor. Bununla birlikte bazı öğretmenlerin motivasyonu yüksek oluyor. Öğretmek için çok çaba gösteriyor. Bunlar hep başarııı olumlu etkiliyor" (K3).

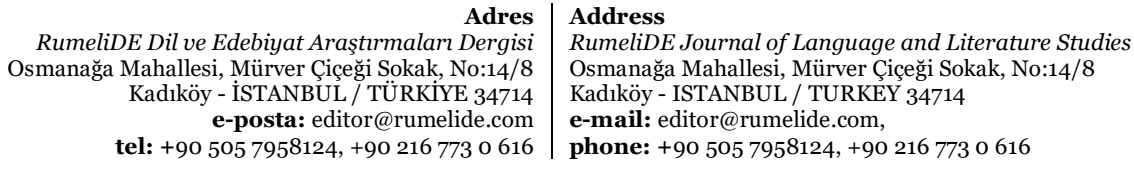


Psikolojisi: Katılımcılara göre yabancı dil olarak Türkçe öğrenenlerin başarısı üzerinde etkili olan unsurlardan bir diğeri öğreticinin psikolojisidir. Aşağıda bu duruma ilişkin bir katılımcı ifadesine örnek olarak yer verilmiştir:

"Her insan gibi öğreticilerin de psikolojileri zaman zaman değişebilir. Bu duygu durumunun sinffa yansıdığın düşünüyorum. Öğretici o gün çok neşeliyse ya da tam tersi çok üzgünse bu ders işleyiş sürecini etkileyecektir. Dolayısıyla öğrenciler de bu süreçte olumlu veya olumsuz olarak etkilenirler. Bu nedenle dil öğrenenlerin başarısında bunun da etkisi vardır.” $\left(\mathrm{K}_{5}\right)$

Kültürel donanımı: Katılımcılara göre yabancı dil olarak Türkçe öğrenenlerin başarısı üzerinde etkili olan unsurlardan biri öğreticinin kültürel donanımıdır. Katılımcılar kültürel donanımı, faklı kültürler hakkında bilgisi olan öğreticilerin, Türkçe öğrenme başarısını olumlu etkilediğini belirtmişlerdir. Aşağıda bu duruma ilişkin bir katılımcı ifadesine örnek olarak yer verilmiştir:

"Bilindiği gibi dil öğretimi ayn zamanda bir kültür öğretimidir. Dolayısıyla öğretici kültürel donanıma sahip olmalı. Bunun yanı stra öğretici kültürlerarası farkındahğa da sahip olmahdır. Farkh kültürlerden gelen öğrencilerimiz var. Onların kültüründe normal olan davranışlar başka bir öğrenci için normal karşılanmayabilir. Dolayısıyla sınıfta çatışmalar yaşanabilir. Ancak kültürel farkındalı̆̆ yüksek öğreticiler bu tür çatışmalarn önüne geçebilir. Dolayısıyla kültürel donanım ve farkındalı

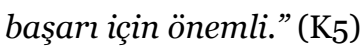

Eğitim durumu: Katılımcılara göre yabancı dil olarak Türkçe öğrenenlerin başarısı üzerinde etkili olan unsurlardan biri de öğreticinin eğitim durumudur. Katılımcılar yabancı dil olarak Türkçe öğretimi üzerine eğitim alan öğreticilerin, öğrenenlerin Türkçe öğrenme başarısını artırdığını ifade etmiştir. Katılımclların bu duruma ilişkin ifadelerinden bir örnek şu şekildedir:

"Ben Türkçe veya dil alanından mezun olması gerektiğini ve bu alanda sertifika alması gerektiğini düşünüyorum. Bu açıdan öğreticinin eğitim durumu öğrenme başarısı üzerinde etkili.” (K4)

Pedagojik yeterliği: Katılımcılara göre yabancı dil olarak Türkçe öğrenenlerin başarısı üzerinde etkili olan unsurlardan bir diğeri öğreticinin pedagojik yeterliğidir. Onlara göre pedagojik yeterliği yüksek olan öğreticiler, öğrenenlerin Türkçe öğrenme başarısını artırmaktadır. Katılımcıların bu duruma ilişkin ifadelerinden bir örnek şu şekildedir:

"Hoca öğrencinin karşısına çıkıyor. Ĕ̆er nasıl anlatacağını çok iyi bilmiyorsa, bir konuyu nasıl aktaracağına çok hâkim değilse öğrenci belki o konuyu çok iyi anlayacak, öğrenci tüm yeterliliklere sahip ama karşısına bunu çok iyi aktaracak bir hoca çıkmadı. Bu sefer öğrenci otomatik olarak konuyu öğrenemeyecek. Yani yemek yapacağız elimizde tüm malzemeler var ama tarif yok nasıl yapılacak o yemek bilmiyoruz. Bazen de hoca konuyu anlatamıor değil ama yanlş̧ anlatıyor. Böyle de olabiliyor. Yani öğreticinin alan bilgisine ve pedagojik yeterliliğe sahip olması şart.” (K3)

\section{Dilsel benzerlikler}

Katılımcılara göre yabancı dil olarak Türkçe öğrenenlerin başarısında etkili olan temel unsurlardan bir diğeri de bilinen dil veya diller ile Türkçe arasındaki dilsel benzerliklerdir. Katılımcılar hedef dil olan Türkçe ile öğrencinin daha önce bildiği diller arasında benzerliklerin olmasının başarıyı artırdığını ifade etmişlerdir. Aşağıda Türkçe öğrenme başarısı üzerinde etkili olduğu ifade edilen dilsel benzerliklere yer verilmiştir.

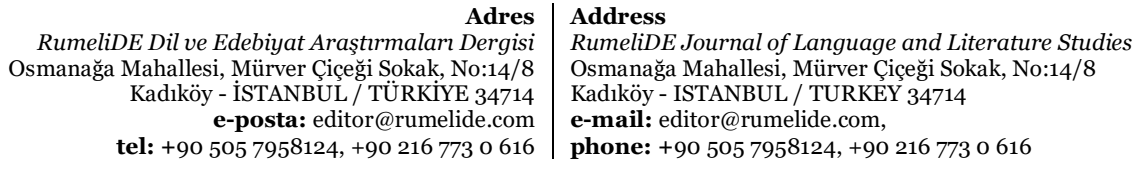




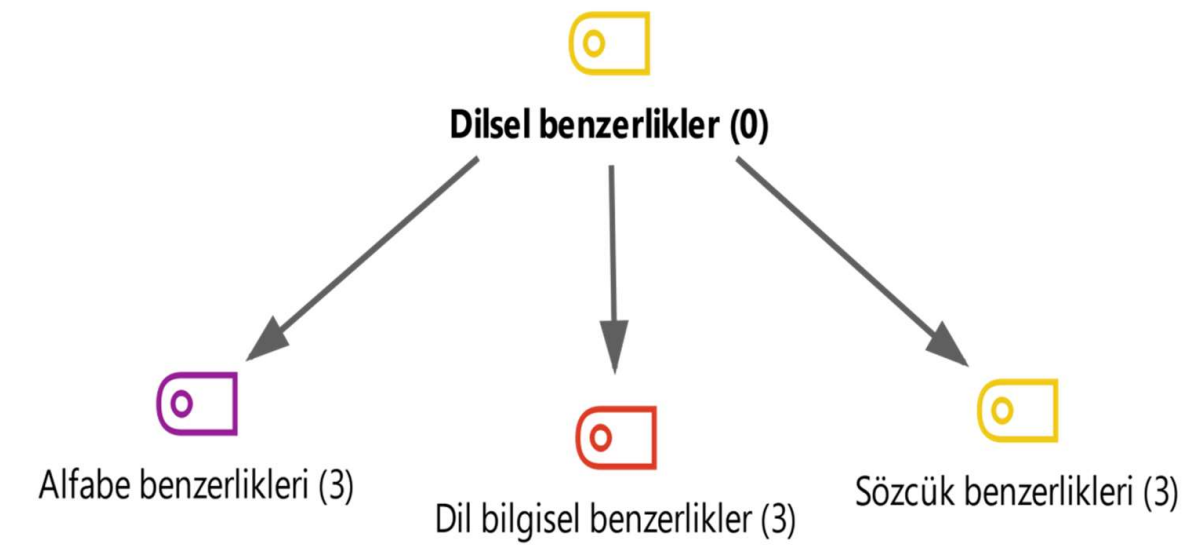

Şekil 4: Katılımcılara göre Türkçe öğrenme başarısı üzerinde etkili olan dilsel benzerlikler

Şekil 4’te görüldüğü gibi katılımcılara göre öğrenci tarafından daha önce bilinen dil ile hedef dil olan Türkçe arasındaki alfabe benzerlikleri ( $\mathrm{f}=3$ ), dil bilgisel benzerlikler $(\mathrm{f}=3)$ ve sözcük benzerlikleri $(\mathrm{f}=3)$ Türkçe öğrenme başarını etkilemektedir. Aşağıda Türkçe öğrenme başarısı üzerinde etkili olduğu ifade edilen bu unsurlar tek tek ele alınmıştır.

Alfabe benzerlikleri: Katılımcılara göre yabancı dil olarak Türkçe öğrenenlerin başarısı üzerinde etkili olan unsurlardan biri öğrencinin bildiği dil ile hedef dil olan Türkçe arasındaki alfabe benzerliğidir. Onlara göre öğrencinin bildiği dil veya diller ile Türkçede aynı alfabe kullanılıyor ise öğrenenlerin Türkçe öğrenme başarısı artmaktadır. Katılımcıların bu duruma ilişkin ifadelerinden bir örnek şu şekildedir:

"Araplara, Farslara alfabe öğretmemiz zaten başl başına bir zamanı kapsıyor. Ama Latin alfabesiyle kendi eğitimlerini alan öğrenciler anlamakta o kadar zorlanmıyor. Mesela ö ve ü sesi öğrencinin kendi dilinde yoksa onun bunu ifade etmesi, kafasında yerleştirmesi zaman alıyor. Mesela çı̆ sesi buradaki “ğ” harfi, ö,ü o,u bunlar söylemeleri o kadar zor ki. Biz dilimize baktığımızda ünlü sesler açısından zengin bir diliz. Bazı dillerde sadece iki ünlü harf var. Çocuk bunu hemen öğrenemez. Konuştuğu toplum içerisinde alıştrrma yaparak deneme yanılma ile zamanla bunu öğrenir. Çünkü bunu kanıksıyor artık. Öğrencileri TÖMER'den mezun ettiğimizde bile çoğu öğrenci bu sesleri tam anlamiyla çlkaramiyordu. Ama mesela mezun olduktan sonra üniversitede farkl çevrelere giriyor, sınf arkadaşlar ile görüşüyor. Bir yıl sonra bizi ziyarete geldiklerinde dillerinde çok gelişme olduğunu fark ediyorduk biz. Dolayısıyla alfabe benzerliği öğrenme başarısında önemli bir faktör." (K1)

Dil bilgisel benzerlikler: Katılımcılara göre yabancı dil olarak Türkçe öğrenenlerin başarısı üzerinde etkili olan unsurlardan biri öğrencinin bildiği dil ile hedef dil olan Türkçe arasındaki dil bilgisel benzerliklerdir. Onlara göre öğrencinin bildiği dil veya diller ile Türkçe arasında dil bilgisel benzerlikler varsa öğrenenlerin Türkçe öğrenme başarısı artmaktadır. Katılımcıların bu duruma ilişkin ifadelerinden bir örnek şu şekildedir:

“Örneğin Amerikah veya Avrupalı öğrenciler 'Ben yapıyor yemek' diyor. Ben sürekli Türkçede eylem sonda olur diye uyarıyorum ama o ısrarla özneden sonra eylem kullanmaya çalş̧ıor. Bu da konuştuğu ve yazdığı her cümlede hata yapmasına sebep oluyor. Bu hatayı engellemek oldukça zor oluyor. Tabii ki zamanla öğreniyor ama ana dili ile öğrendiği dil arasinda dil bilgisel farkhllklar olmasından dolayı çok fazla zorluk yaşıyor. Ama Rus öğrenci çok kolay öğreniyor. Mesela diyor ki

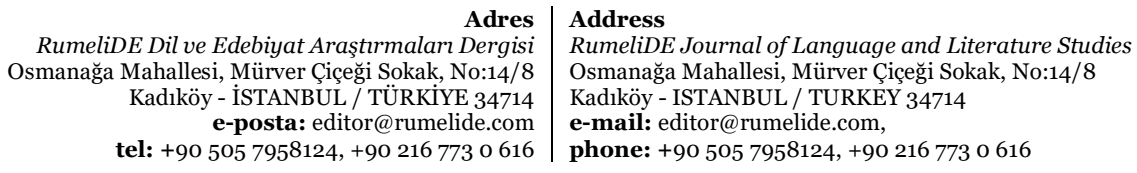


'Bizde de ekler varder eklerle yeni kelimeler üretiriz ve biz de eylemi sonda kullanırzz.' Rus öğrencilerin çok nadir başarısız olduğunu görüyoruz.”(K2)

Sözcük benzerlikleri: Katılımcılara göre yabancı dil olarak Türkçe öğrenenlerin başarısı üzerinde etkili olan unsurlardan biri öğrencinin bildiği dil ile hedef dil olan Türkçe arasındaki sözcük benzerlikleridir. Onlara göre öğrencinin bildiği dil veya diller ile Türkçede aynı veya benzer sözcükler yer alıyorsa öğrenenlerin Türkçe öğrenme başarısı artmaktadır. Katılımcıların bu duruma ilişkin ifadelerinden bir örnek şu şekildedir:

"Sözcük benzerlikleri önemli. Çünkü burada öğreticilikten bir adım öteye giden bir durum. Biliyorsunuz son yıllarda kültürlerarasıllk, diller arası etkileşim çok önemli. Siz onun dünyasından ortak bir sözcük söylediğinizde çocukta da olumlu bir tutum gelişebiliyor. Mesela siz Türkçe öğretirken "Merhaba" diyorsunuz, çocuk 'Aaaa hocam bu bizde de merhaba.' diyor. Arapça ve Farsçada zaten inanlmaz bir benzerlik var. Batı dillerinde İspanyolca santrm 'Baba' kelimesi vardı. Bu benzerlikler daha güzel bir ortam oluşmasına imkân sağliyor. Bu benzerlikler öğrencinin hoşuna gidiyor, öğrenme başarısını etkiliyor.” (K4)

\section{Kullanian Materyaller}

Katılımcılara göre Yabancı dil olarak Türkçe öğrenenlerin başarısında etkili olan temel unsurlardan biri de kullanılan materyallerdir. Katılımcılar kullanılan ders kitaplarının ( $\mathrm{f}=2)$, etkileşimli kitapların ( $\mathrm{f}=2)$, otantik materyallerin $(\mathrm{f}=2)$ ve teknolojik araçların $(\mathrm{f}=2)$ öğrenme başarısı üzerinde etkili olduğunu ifade etmişlerdir. Aşağıda Türkçe öğrenme başarısı üzerinde etkili olduğu ifade edilen bu materyallere yer verilmiştir.

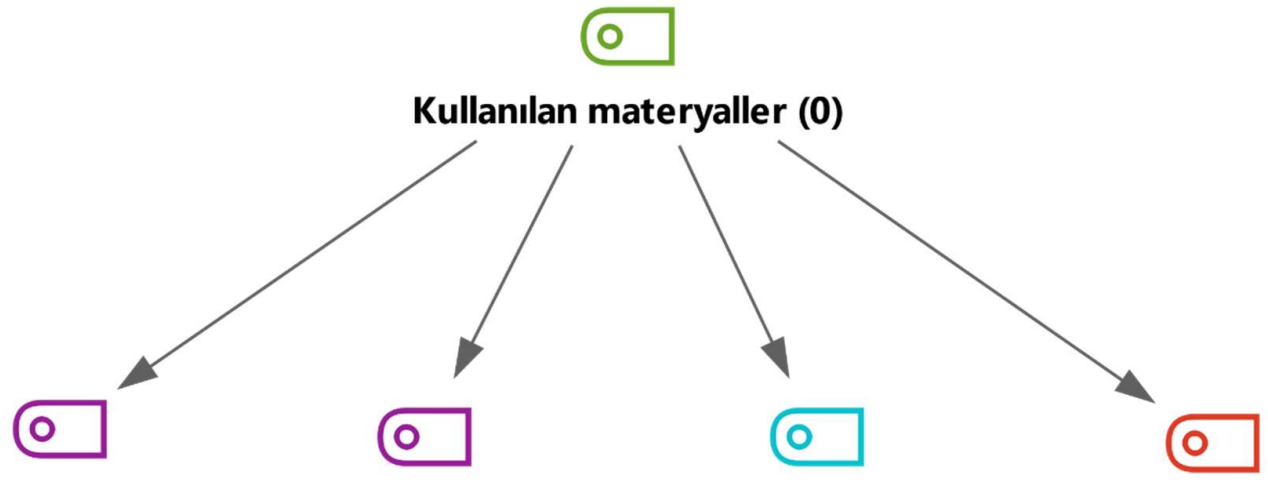

Ders kitapları (2) Etkileşimli kitaplar (2) Otantik materyaller (2) Teknolojik araçlar (2)

Şekil 5: Katılımcılara göre Türkçe öğrenme başarısı üzerinde etkili olan materyaller

Ders kitapları: Katılımcılara göre yabancı dil olarak Türkçe öğrenenlerin başarısı üzerinde etkili olan unsurlardan biri ders kitaplarıdır. Onlara göre ders kitapları nitelikli olduğunda Türkçe öğrenme başarısı artmaktadır. Katılımcıların bu duruma ilişkin ifadelerinden bir örnek şu şekildedir:

"Ders kitapları öğrenmelerini çok fazla etkiliyor. İyi hazırlanmış kitaplar öğrencileri olumlu şekilde etkiliyor. Ama çok gereksiz bilgiler içeren kitaplar öğrenciyi rüzgâr gibi oradan oraya savuruyor. Öğrenci sürekli 'Bu ne demek, şunu da anlatmadını.' diyebiliyor. O konu aslında gerekli değil hatta bilmese onun için daha iyi. Bu yüzden kitaplar gereksiz bilgilerden uzak ve nitelikli olmal..” (K3)

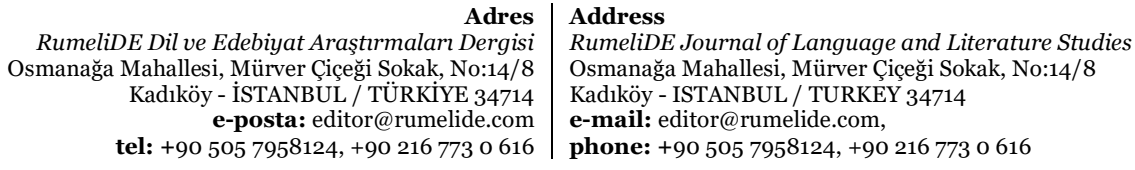


Etkileşimli kitaplar: Katılımcılara göre yabancı dil olarak Türkçe öğrenenlerin başarısı üzerinde etkili olan unsurlardan biri de kullanılan etkileşimli kitaplardır. Katılımcılara göre bu kitaplar öğrenme başarısını artırmaktadır. Aşağıda katılımcıların bu duruma ilişkin ifadelerinden bir örneğe yer verilmiştir.

"Bu kitaplar sayesinde kısa sürede daha çok şey öğretebiliyoruz. Güzel ilerliyor. Vakit kaybı olmuyor. Eskiden cd tak dinle vs. zordu. Şuan çok daha kolay. Zaten öğrencinin kullandiğı materyal bence öğrenmesini çok çok etkiliyor.” $\left(\mathrm{K}_{3}\right)$

Otantik materyaller: Katılımcılara göre yabancı dil olarak Türkçe öğrenenlerin başarısı üzerinde etkili olan unsurlardan bir diğeri de kullanılan otantik materyallerdir. Katılımcılar otantik materyallerin öğrenenlerin Türkçe öğrenme başarını olumlu etkilediğini ifade etmiştir. Aşağıda katılımcıların bu duruma ilişkin ifadelerinden bir örneğe yer verilmiştir:

“Öğrencinin gerçek hayatta karşılaştığı durumları sınıf ortamına taşımakta bu materyaller bir araç. Faydalanıyor muyuz? Bazen faydalanyoruz ama ben kendi adıma biraz yetersiz olduğumu düşünüyorum. Çünkü derste süre yetmeyebiliyor bu materyalleri kullanmak için. Ama bu materyalleri fazlaca kullanmanı başarı üzerinde etkili olduğunu düşünüyorum. Bir de materyallerin yaşa göre düzenlenmesi gerekiyor." (K4)

Teknolojik araçlar: Katılımcılara göre yabancı dil olarak Türkçe öğrenenlerin başarısı üzerinde etkili olan unsurlardan biri de kullanılan teknolojik araçlardır. Katılımcılar öğrenme amaçlı kullanılan teknolojik araçların öğrenenlerin Türkçe öğrenme başarını olumlu etkilediğini ifade etmiştir. Aşağıda katılımcıların bu duruma ilişkin ifadelerinden bir örneğe yer verilmiştir.

“Öğrenme ortamlarında öğrencinin dikkatini çekmekte onlarl yönlendirmekte materyaller çok büyük bir işleve sahiptir. Materyallerin öğrencilerin öğreneceği konuya ilişkin uyumlu bir şekilde işlevsel bir şekilde kullanılması çok önemlidir. Sadece materyal kullanmak çözüm değil. Konuya öğrenciye uygun materyallerin seçilip kullanılabilmesi dil öğretiminde başarnyı getirir. Krashen ne diyor 'Dil anlaşılabilir girdiler sunulduğu sürece öğrenilir.' Yani girdiyi siz materyallerle anlaşılabilir hâle sokacaksınız. İşlevsel bir materyal seçimi dil öğretiminde öğrencinin başarıya ulaşmasını sağlar.” (K1)

\section{Geri Bildirimler}

Katılımcılara göre yabancı dil olarak Türkçe öğrenenlerin başarısında etkili olan temel unsurlardan biri de geri bildirimlerdir. Katılımcılar Türkçe öğrenme sırasında öğretmenler veya akranlar tarafından sunulan olumlu ( $\mathrm{f}=3$ ) ve olumsuz $(\mathrm{f}=2$ ) geri bildirimlerin öğrenenlerin öğrenme başarısı üzerinde etkili olduğunu ifade etmişlerdir. Aşağıda Türkçe öğrenme başarısı üzerinde etkili olduğu ifade edilen bu geri bildirimlere yer verilmiştir.

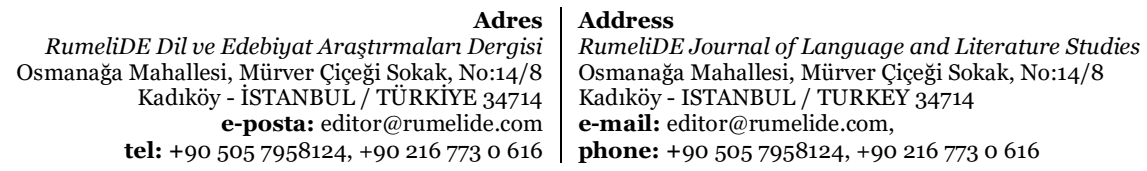

Adres
RumeliDE Dil ve Edebiyat Araşttrmaları Dergisi Kadı̈̈̈y - ISTANBU̧ / TÜR,YE 34714 tel: +90 $5057958124,+902167730616$

phone: +90 505 7958124, +90 2167730616 


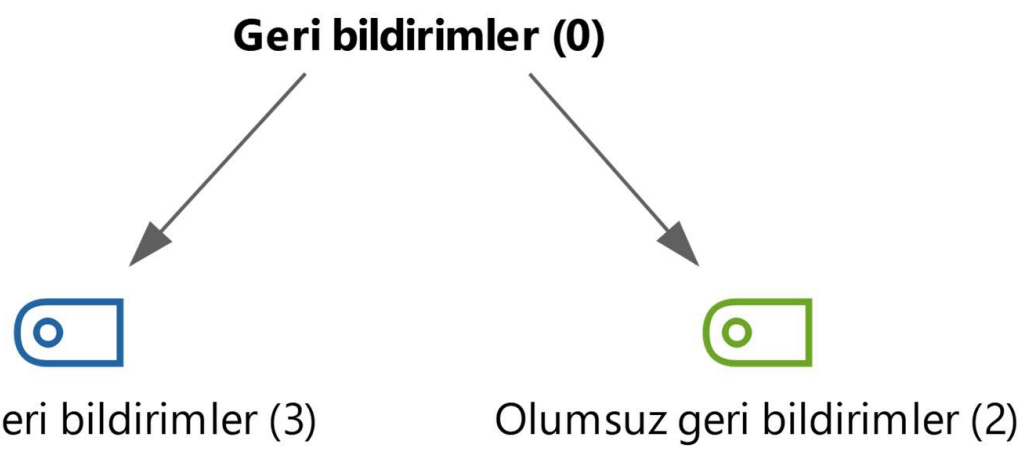

Olumlu geri bildirimler (3)

Olumsuz geri bildirimler (2)

Şekil 6: Katılımcılara göre Türkçe öğrenme başarısı üzerinde etkili olan geri bildirimler

Olumlu geri bildirimler: Katılımcılar olumlu geri bildirimlerin Türkçe öğrenme başarını etkilediğini ifade etmiştir. Aşă̆ıda katılımcıların bu duruma ilişkin ifadelerinden bir örneğe yer verilmiştir.

“Öğreticinin geri bildirim vermesi öğrencilerin kendi hataların görmesi açısından oldukça önemli. Fakat geri bildirim sadece öğrencinin hatasın düzeltmek anlamına gelmiyor. Örneğin öğrenci Türkçe konuşmaya çalışıyor ama bazı hatalar yapıyor. Öğretici burada hataları görmek yerine onun konuşmaya teşvik etmek adına 'Evet çok güzel, devam et vb.' gibi ifadelerle geri bildirimde bulunduğunda öğrenci psikolojik olarak rahatlıyor ve daha çok çaba gösteriyor. Bu da başarıyı beraberinde getiriyor.” $\left(\mathrm{K}_{5}\right)$

Olumsuz geri bildirimler: Katılımcılar olumsuz geri bildirimlerin Türkçe öğrenme başarını etkilediğini ifade etmiştir. Aşağıda katılımcıların bu duruma ilişkin ifadelerinden bir örneğe yer verilmiştir.

"Bu başarıyı oldukça etkiliyor. Bir öğreticiyi gözlemleme imkânım oldu. Öğrenci bir şeyin cevabın yanlş̧ söyledi. Ama hoca o yanlş̧ı düzeltmedi yani bir geri bildirimde bulunmadı. Düzeltme yapmayınca öğrenci yaptı̆̆ hatayı doğru olarak kabul etti. Yani yanlışını göremedi. Sonrasında biz hatasın söyledik ve ona farkındalık kazandırdık.” $\left(\mathrm{K}_{3}\right)$

\section{Öğrenme ortamları}

Katılımcılara göre yabancı dil olarak Türkçe öğrenenlerin başarısında etkili olan temel unsurlardan biri de öğrenme ortamlarıdır. Katılımcılar sosyal çevrenin ( $\mathrm{f}=5)$, otantik ortamların ( $\mathrm{f}=2$ ) ve sınıf ortamının $(\mathrm{f}=3)$ öğrenenlerin Türkçe öğrenme başarısı üzerinde etkili olduğunu ifade etmişlerdir. Aşağıda Türkçe öğrenme başarısı üzerinde etkili olduğu ifade edilen bu unsurlara yer verilmiştir.

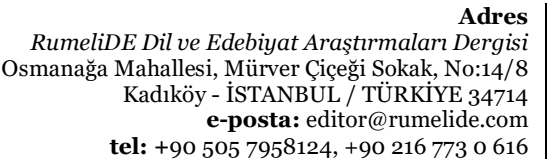

dres

RumeliDE Journal of Language and Literature Studies

Osmanağa Mahallesi, Mürver Çiçeği Sokak, No:14/8

Kadıköy - ISTANBUL / TURKEY 34714

e-mail: editor@rumelide.com,

phone: +90 $5057958124,+902167730616$ 


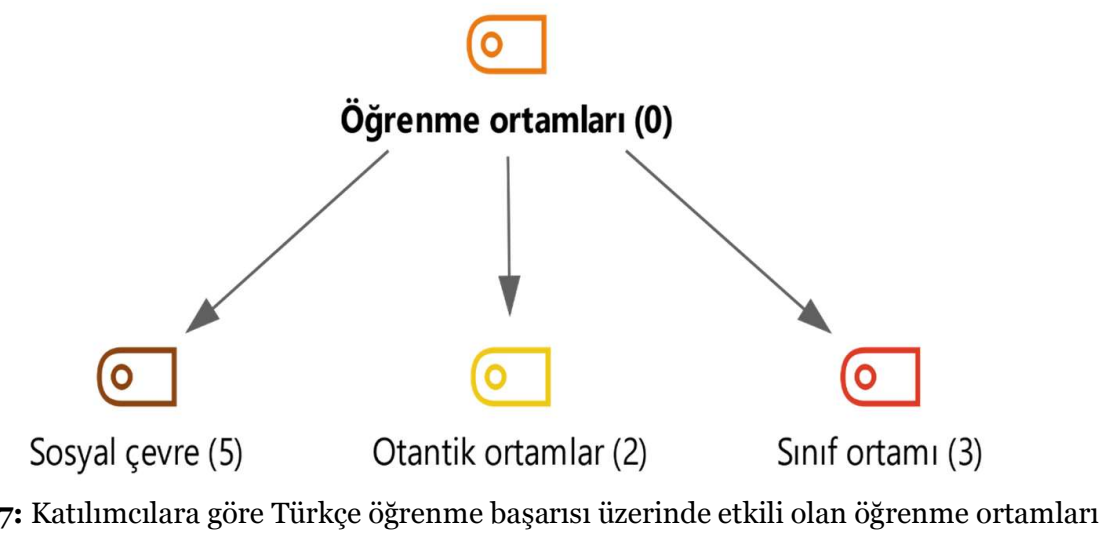

Sosyal çevre: Katılımcılara göre yabancı dil olarak Türkçe öğrenenlerin başarısı üzerinde etkili olan unsurlardan biri de öğrenme sürecinde içinde bulunulan sosyal çevredir. Katılımcllar öğrenenin içerisinde bulduğu sosyal çevrenin Türkçe öğrenme başarısı açısından önemli olduğunu ifade etmiştir. Aşağıda katılımcıların bu duruma ilişkin ifadelerinden bir örneğe yer verilmiştir.

"Kesinlikle sosyal çevre başarıyı etkiler. Yani öğrendiğimiz dilin konuşulduğu ortamda olmamız bizim dil öğrenmemizi çok kolaylaşttrıyor. Bu bağlamda Türkiye'de Türkçe öğrenen öğrencilerimizin TÖMER sinıflarında çıktıktan sonra gerek öğreticilerin yardımı gerekse öğrencilerin kendi çabalarıla Türklerle iletişime geçebilecekleri ortamlar yaratılması lazım. Bu ortamlarda kullandığımız bazı stratejiler veya yöntemler var. Bunlara biz dil partnerliği, akran danışmanlğ̆ı, tutor destekli öğretim diyoruz. Bu tür yöntemlerin istikrarlı bir şekilde kullanılması öğrencileri dili kullanmaya, konuşmaya yönlendirdiği için çok etkili olmaktadır. Bunlar bütüncül olarak devreye sokulduğunda öğrenci başarıya ulaşıyor.”(K1)

Otantik ortamlar: Katılımcılara göre yabancı dil olarak Türkçe öğrenenlerin başarısı üzerinde etkili olan unsurlardan bir diğeri öğrenme sürecinde içinde bulunulan otantik ortamlardır. Katılımcılar öğrenenin içerisinde bulduğu otantik ortamların Türkçe öğrenme başarısı açısından önemli olduğunu ifade etmiştir. Aşağıda katılımcıların bu duruma ilişkin ifadelerinden bir örneğe yer verilmiştir.

“Biz yıllar önce Ankara Üniversitesi TÖMER'de otantik simıf oluşturmuştuk. Sinıfin bir bölümünü manav yaptık, bir yerini alışveriş merkezi yaptık ve herkes evde kullanmadiğı eşarp, şapka vb. malzemeleri getirdi. Bazı öğrenciler plastik meyve sebze getirdiler. Konuşma kulübü gibi bir yer oluştu. İsteyen öğrencilerle pratik yaptık çok eğlenceli ve öğretici olmuştu.” (K2)

Stnıf ortamı: Katılımcılara göre yabancı dil olarak Türkçe öğrenenlerin başarısı üzerinde etkili olan unsurlardan bir diğeri de sınıf ortamıdır. Katılımcılar öğrenenin içerisinde bulduğu sınıf ortamının Türkçe öğrenme başarısı açısından önemli olduğunu ifade etmiştir. Aşağıda katılımcıların bu duruma ilişkin ifadelerinden bir örneğe yer verilmiştir.

“Ses, ısı, ışık, gürültü bu tür ortamlar öğrenci başarısını etkiler. Düşünün Türkçe öğrettiğiniz ortamda 4 ay boyunca bir inşaat çalş̧ması var. Mersin'e iki yıl önce Suriyeli öğrencileri gözlemlemek için gittim. Öğrencilere 'Nasıl gidiyor arkadaşlar?' dediğimde 'Hocam sıcaktan ölüyoruz sinıfta klima yok' dediler. Bu öğrenciler hamam gibi sımfflarda Türkçe öğreniyor ve biz onlardan büyük bir istekle derse katılmaların bekliyoruz. Artık sınıf içinde de U düzeni oluşturulmasım ısrarla tavsiye ediyoruz. Öğrenci geleneksel sira düzeninde birbirinin ensesini görerek dil öğrenemez, etkileşim olmaz. Bizler

Adres Address

RumeliDE Dil ve Edebiyat Araşturmaları Dergisi $\quad$ RumeliDE Journal of Language and Literature Studies Osmanağa Mahallesi, Mürver Çiçeği Sokak, No:14/8 $\quad$ Osmanağa Mahallesi, Mürver Çiçeği Sokak, No:14/8 Kadıköy - ÍSTANBUL / TÜRKIYE 34714 Kadıköy - ISTANBUL / TURKEY 34714 e-posta: editor@rumelide.com e-mail: editor@rumelide.com, tel: +90 505 7958124, +90 2167730616 phone: +90 505 7958124, +90 2167730616 
her öğrenciyle bire bir ilgilenmeliyiz, göz teması kurmahyız. U düzeni ile sınıfa hâkim olabiliyoruz ve her öğrenciye eşit mesafede oluyoruz. Bunlar çok önemli.”(K2)

\section{Tartışma ve sonuç}

Araştırmada elde edilen veriler öğreticilere göre yabancı dil olarak Türkçe öğrenenlerin başarısını etkileyen altı temel unsur olduğunu göstermiştir. Bu temel unsurlar; öğrencinin özellikleri, öğreticinin özellikleri, kullanılan materyaller, dilsel benzerlikler, geri bildirimler ve öğrenme ortamlarıdır. Aşağıda yabancı dil olarak Türkçe öğrenenlerin başarısında etkin rol oynadığı ifade edilen bu temel unsurların her biri alanyazında yer alan diğer çalışmaların da bulguları ile birlikte ele alınarak tartışılmıştır:

Araştırmada yabancı dil olarak Türkçe öğrenenlerin başarısını etkileyen temel unsurlardan birinin öğrencinin kendi özellikleri olduğu görülmüştür. Öğreticilere göre öğrencinin motivasyonu, kültürel donanımı ve uyumu, eğitim durumu, teknolojik yeterliği, yaşı, özerkliği, psikolojisi, ana dilindeki yeterliği, birden çok dil bilmesi ve kişilik özellikleri Türkçe öğrenme başarısını etkilemektedir. Alyılmaz'da (2018) Türkçenin yabancı dil olarak öğretiminde öğrenenlerin öneminden bahsetmiş ve öğrenenin yaşı, ana dili, cinsiyeti, kültürü, motivasyonu gibi unsurların başarı açısından önemli olduğunu ifade etmiştir. Bununla birlikte birçok araştırmada öğrenci motivasyonunun dil öğrenme başarısı üzerinde etkili olduğu ifade edilmiştir (Dörnyei, 1998; Ebata, 2008; Engin, 2009; Mahadi ve Jafari, 2012; Nakata, 2006). Ayrıca gerçekleştirilen birçok çalışmada yabancı dil öğreniminde kültürün önemine değinilmiş ve kültürel unsurların dil öğretiminden ayrı düşünülemeyeceğine vurgu yapılmıştır (Byram ve Feng, 2004; Çakır, 2011; MacDonald, Badger ve Dasli, 2006). Bununla birlikte Sarıçoban ve Çalışkan (2011) hedef dile ait kültürel bilgilerin sınıf içi etkinliklerde kullanılmasının öğrenciler üzerindeki olumlu etkilerinden bahsetmişlerdir. Dolayısıyla bu çalışmada elde edilen verilerin öğrencinin motivasyonu, kültürel donanımı, yaşı, ana dili, cinsiyeti gibi unsurların önemini ifade eden bu çalışmalar ile uyumlu olduğu söylenebilir.

Araştırmada öğreticilerin özelliklerinin yabancı dil olarak Türkçe öğrenenlerin başarısında belirleyici bir unsur olduğu görülmüştür. Katılımcılara göre öğreticilerin alan bilgisi, kişilik özellikleri, teknolojik yeterliği, yaşı, tutumu ve motivasyonu, psikolojisi, kültürel donanımı, eğitim durumu ve pedagojik yeterliği yabancı dil olarak Türkçe öğrenenlerin başarısını etkileyebilmektedir. Özer ve Korkmaz (2016) tarafından gerçekleştirilen araştırmada da yabancı dil öğreniminde öğretmen davranışlarının başarıyı etkileyebildiği ifade edilmiştir. Bununla birlikte gerçekleştirilen birçok çalışmada öğretmen tarafından benimsenen öğretim yönteminin başarı açısından önemli olduğu ifade edilmiştir (Altmışdört, 2010; Engin, 2009; Nguyen, Warren ve Fehring, 2014; Türkoğlu, 2004). Çakır (2011) ise dil öğretiminde öğretmenin her iki kültür konusunda yeterli donanıma sahip olması gerektiğini aksi hâlde bunun yanlış anlaşılmaya veya uygulamaya yönelik başarısızlı̆̆a sebep olacağını ifade etmiştir. Dolayısıyla bu çalışmada elde edilen verilerin öğreticinin tutumu ve motivasyonu, pedagojik yeterliği, kültürel donanımı gibi unsurların önemini ifade eden bu çalışmalar ile uyumlu olduğu söylenebilir.

Araştırmada elde edilen veriler öğrenenler tarafından bilinen diller ile hedef dil olan Türkçe arasındaki benzerliklerin yabancı dil olarak Türkçe öğrenenlerin başarısında etkili olan temel bir unsur olduğunu göstermiştir. Öğreticilere göre öğrenenlerin bildikleri diller ile Türkçe arasındaki alfabe benzerliği, dil bilgisel benzerlikler ve sözcük benzerlikleri onların Türkçe öğrenme başarısını etkilemektedir. Şengül'de (2014) gerçekleştirdiği çalışmada Türkçenin yabancı dil olarak öğretiminde alfabe sorununa değinmiş ve farklı alfabeler kullanan yabancı uyruklu öğrencilerin çeşitli sıkıntılar yaşadığını belirtmiştir. Bununla birlikte Biçer (2017) tarafından gerçekleştirilen çalışmada Türkçenin yabancı dil olarak

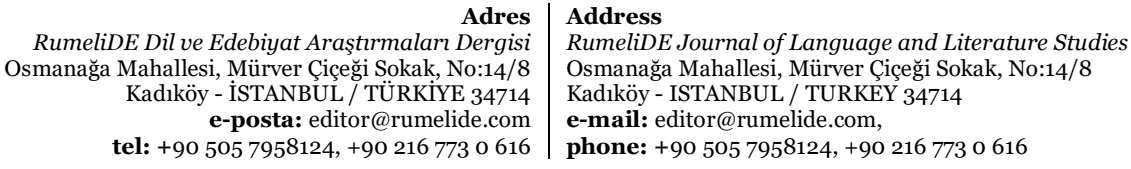


öğretiminde ana dilinin etkisine değinilmiş ve öğrencilerin kendi dillerinden aktarım yapabildikleri belirtilmiştir. Bu çalışmada da öğrencilerin kendi dillerinin veya bildiği dillerin Türkçe öğrenme başarısı açısından önemli olduğu görülmüştür.

Araştırmada elde edilen veriler kullanılan materyallerin yabancı dil olarak Türkçe öğrenenlerin başarısında etkili olan temel bir unsur olduğunu göstermiştir. Öğreticilere göre kullanılan ders kitapları, etkileşimli kitaplar, otantik materyaller, teknolojik araç ve gereçler öğrenenlerin başarısını etkilemektedir. Çelik (2018) gerçekleştirdiği çalışmada Türkçenin yabancı dil olarak öğretiminde otantik materyallerin önemine değinmiş ve otantik materyal kullanımının yetersiz olduğunu belirtmiştir. Bununla birlikte Karababa ve Taşkın (2012) yabancı dil olarak Türkçe öğretiminde kullanılan ders kitaplarının önemine değinmiştir. Ayrıca Günaydın ve Arıcı (2020) Türkçenin yabancı dil olarak öğretiminde etkileşimli okumanın konuşma becerisi üzerinde olumlu etkilerinin olduğunu ifade etmiştir. Baş ve Yıldırım (2018) ise yabancılara Türkçe öğretiminde teknolojinin öneminden bahsetmiş ve kullanılan Web 2.0 araçlarının öğrencilerin motivasyonlarını geliştirdiğini, yaratıcılıklarına katkı sağladığını, dil öğreticilerine esnek imkanlar sunduğunu belirtmişlerdir. Tüm bunlar kullanılan materyallerin Türkçe öğrenenlerin başarısı açısından son derece önemli olduğunu göstermektedir.

Araştırmada elde edilen veriler geri bildirimlerin yabancı dil olarak Türkçe öğrenenlerin başarısında etkili olan bir diğer unsur olduğunu göstermiştir. Öğreticilere göre olumlu ve olumsuz geri bildirimler öğrenenlerin başarısını etkilemektedir. Çetinkaya ve Hamzadayı (2015) gerçekleştirdikleri çalışmada yabancı dil olarak Türkçe öğretim sürecinde geri bildirimlerin önemine değinmişler ve bu süreçte öğrencilerin konuşma yanlışlarının anadili Türkçe olan öğreticiler tarafından düzeltilmesini beklediklerini belirtmişlerdir. Kılıç (2017) ise gerçekleştirdiği çalışmada dolaylı ve doğrudan geri bildirimlerin yabancı dil olarak Türkçe öğrenen öğrencilerin iyelik ve hâl eklerini öğrenmelerinde etkili olduğunu belirtmiştir. Öte yandan Kardaş ve Cömert (2021) Türkçenin yabancı dil olarak öğretiminde geri bildirimlerle yapılan dil bilgisi öğretiminin başarıyı artırdığını belirtmiştir. Tüm bunlar yabancı dil olarak Türkçe öğrenenlerin başarısında geri bildirimlerin önemli bir unsur olduğunu göstermektedir.

Araştırmada elde edilen veriler öğrenme ortamlarının yabancı dil olarak Türkçe öğrenenlerin başarısında etkili olan bir diğer unsur olduğunu göstermiştir. Öğreticilere göre öğrenenlerin içerisinde bulunduğu sosyal çevre, otantik öğrenme ortamları ve sınıf ortamları onların Türkçe öğrenme başarısını etkilemektedir. Kınay (2017) yabancı dil olarak Türkçe öğretimi sınıflarında sosyal etkinliklere katılan öğrencilerin katılmayanlara göre daha etkili bir öğrenim gerçekleştirdiklerini belirtmiştir. Özdemir, Özkan, De Chiara, Demir, Kara ve Kınsız (2014) yabancı dil olarak Türkçe öğretiminde sosyal etkinliklerin öğrenci performansına çeşitli olumlu yansımalarının olduğunu belirtmiştir. Tüm bunlar yabancı dil olarak Türkçe öğrenenlerin başarısında öğrenme ortamlarının önemli olduğunu göstermektedir.

\section{Öneriler}

1. Araştırmada Türkçe öğrenenlerin başarısını etkileyen unsurlardan birinin öğrenci motivasyonu olduğu tespit edildiğinden öğrencilerin motivasyonunu yüksek tutmak için Türkçe öğretim ortamlarının eğlenceli ve dikkat çekici hâle getirilmesi önerilebilir. Türkçe öğretim ortamlarının eğlenceli hâle getirilmesi içinse drama, tartışma, istasyon, altı şapkalı düşünme gibi onları aktif katılıma teşvik eden yöntem ve tekniklere başvurulması tavsiye edilebilir.

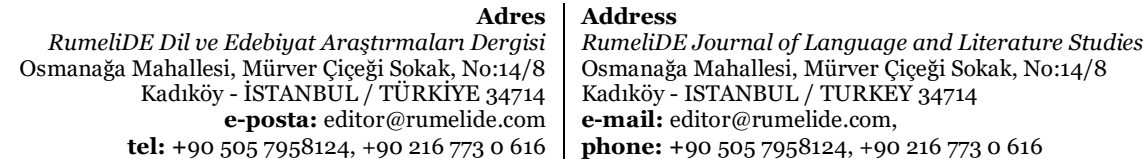


2. Araştırma sonucuna göre hem öğrenenin hem de öğreticinin teknolojiye hâkim olmasının başarıyı etkilediği görüldüğünden teknolojik yeterliliklere sahip öğreticilerin başarılı bir öğretim süreci gerçekleştirileceği öngörülmektedir. Bunun için öğreticilere yönelik hizmet içi eğitimler düzenlenmesi önerilebilir.

3. Araştırmada Türkçe öğrenenlerin başarısını etkileyen diğer bir unsurun kültürel etmenler olduğu tespit edildiği için yabancı dil olarak Türkçe öğrenenlere Türk kültürünün tanıtılması amacı ile sınıf içi ve sınıf dışında çeşitli etkinliklerin gerçekleştirilmesi tavsiye edilebilir. Türkiye'de Türkçe öğrenen öğrenciler müze ziyareti, kültür gezisi vb. sınıf dışı etkinlikler ile gerçek ortamlara sokularak dili işlevsel olarak kullanmaya teşvik edilebilir.

4. Bulgulara göre yabancı dil olarak Türkçe öğrenenlerin başarısını etkileyen diğer bir unsur kullanılan materyallerdir. Türkçe öğretiminde işlevsel materyaller seçilmelidir. Ayrıca bu materyallerin aynı sıra öğrenme ortamlarına dergi, gazete, takvim vb. gibi otantik materyaller getirilerek öğrenci motivasyonları artırılabilir.

5. Araştırmada elde edilen bulgular sınıf ortamının Türkçe öğrenme başarısı açısından önemli olduğunu göstermiştir. Bu nedenle sınıf ortamının öğrencilerin etkileşimde bulunabileceği şekilde tasarlanması yararlı olacaktır. Öğrenciler arasındaki etkileşimin artırılması amacı ile yabancı dil olarak Türkçe öğretiminin gerçekleştirildiği sinıflarda U oturma düzeni oluşturulabilir.

6. Araştırmada sosyal çevrenin ve otantik ortamların Türkçe öğrenme başarısı açısından önemli görüldüğü tespit edilmiştir. Bu nedenle özellikle yurt dışında Türkçe öğrenen öğrencilerin Türkçeye daha fazla maruz kalmaları amacıyla otantik ortamlar oluşturulmalıdır. Örneğin öğreticiler sınıf içi etkinliklerde dergi, gazete, takvim, sinema bileti vb. materyaller kullanarak bu tür ortamlar oluşturabilir.

\section{Kaynakça}

Alpar, M. (2013). Yabancı dil öğretiminde kültürel unsurların önemi. Journal of Language and Linguistic Studies, 9(1), 95-106. http://www.jlls.org/index.php/jlls/article/view/140/139

Alsayed, M. (2003). Factors That Contribute to Success in Learning English as a Foreign Language, Damascus University Journal, 19, (1+2), 21-44. http://www.damascusuniversity.edu.sy/mag/human/images/stories/o3230.pdf

Altmışdört, G. (2010). Yabancı Dil Öğretiminde Nasıl Bir Ölçme Değerlendirmeye Gerek vardır? Kuramsal Ĕ̆itimbilim, 3 (2), 175-200. https://keg.aku.edu.tr/arsiv/c3s2/c3s2m13.pdf

Alyılmaz, S. (2018). Türkçenin Yabancı Dil Olarak Öğretiminde Hedef Kitlenin/“Öğrenen” İn Önemi. Uluslararası Türkçe Edebiyat Kültür Eğitim (TEKE) Dergisi,7(4), 2452-2463. https://dergipark.org.tr/tr/pub/teke/issue/42447/511176

Bao, Y. ve Liu, S. (2021). The Influence of Affective Factors in Second Language Acquisition on Foreign Language Teaching. Open Journal of Social Sciences, 9, 463-470. http://dx.doi.org/10.4236/jss.2021.93030.

Baş, B., ve Yıldırım, T. (2018). Yabancılara Türkçe öğretiminde teknoloji entegrasyonu. Ana Dili Ĕ̆itimi Dergisi. 6(3), 827-839. http://dx.doi.org/10.16916/aded.415059

Biçer, N. (2017). Türkçenin yabancı dil olarak öğretiminde ana dilinin etkisi. Electronic Turkish Studies, 12(14), 41-58. http://dx.doi.org/10.7827/TurkishStudies.11704

Büyüköztürk, Ş, Kılıç Çakmak, E, Akgün, O.E, Karadeniz, Ş ve Demirel F. (2016). Bilimsel araştırma yöntemleri. [Scientific research methods]. Ankara: Pegem Akademi.

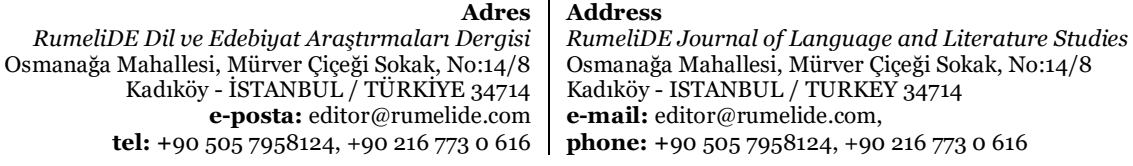


The instructors' views on factors affecting the success of learners learning Turkish as a foreign language / A. Demirel; Ç. Yalçın (pp. 22-43)

Byram, M., ve Feng, A. (2004). Culture and language learning: Teaching, research and scholarship. Language Teaching, 37(3), 149-168. http://dx.doi.org/10.1017/So261444804002289

Çakır, İ. (2011). Yabancı dil öğrenme ortamlarında kültürün rolü. Milli Eğitim Dergisi, 41(190), 248255. https://dergipark.org.tr/tr/pub/milliegitim/issue/36192/406923

Çelebi, M. D. (2006). Türkiye'de anadili eğitimi ve yabancı dil öğretimi. Erciyes Üniversitesi Sosyal Bilimler Enstitüsü Dergisi, 1(21), 285-307. https://dergipark.org.tr/tr/pub/erusosbilder/issue/23754/253119

Çelik, M. E. (2018). Türkçenin Yabancı dil olarak öğretiminde otantiklik ve otantik materyallerden yararlanma. 21. Yüzyılda Eğitim Ve Toplum Eğitim Bilimleri Ve Sosyal Araştırmalar Dergisi, 7(21), 791-806. https://dergipark.org.tr/tr/pub/egitimvetoplum/issue/43608/534007

Çetinkaya, G. ve Hamzadayı, E. (2015). Yabancı dil olarak Türkçe öğretim sürecinde sözel düzeltme geribildirimleri: Öğretmen ve öğrenci yeğleyişleri. Turkish Studies, 1O(3), 285-302. http://dx.doi.org/10.7827/TurkishStudies.7906

Dörnyei, Z. (1998). Motivation in second and foreign language learning. Language Teaching, 31(3), 117135. http://dx.doi.org/10.1017/So26144480001315X

Ebata, M. (2008). Motivation factors in language learning. The Internet TESL Journal, 14(4). http://iteslj.org/Articles/Ebata-MotivationFactors.html

Engin, A. O. (2009). Second language learning success and motivation. Social Behavior and Personality: An International Journal, 37(8), 1035-1041. http://dx.doi.org/10.2224/sbp.2009.37.8.1035

Er, K. O. (2006). The effects of culture in foreign language curriculum, Ankara Üniversitesi Eğitim Bilimleri Dergisi, 39 (1), 1-14. https://doi.org/10.1501/Egifak_0000000128

Günaydın, Y. ve Arıcı, A. F. (2020). Türkçenin yabancı dil olarak öğretiminde etkileşimli okumanın konuşma becerisine etkisi. EKEV Akademi Dergisi, 24 (83), 673-696. http://dx.doi.org/10.17753/Ekev1688

Karababa, Z. C. ve Üstünsoy Taşkın, S. (2012). Yabancı dil olarak Türkçe öğretiminde kullanılan ders kitaplarının öğretmen görüşleri çerçevesinde değerlendirilmesi. Dil Dergisi, 157, 65-80. https://dergipark.org.tr/tr/download/article-file/780083

Kardaş, D. M. ve Bayrak Cömert, Ö. , (2021). Yabancılara Türkçe Dil Bilgisi Öğretiminde Geribildirimin Öğrenici Başarısına Etkisi Üzerine Bir Araştırma. Turkish Studies-Educational Sciences, 16(1), 423-434. http://dx.doi.org/10.47423/turkishstudies.47818

Kılıç, İ. (2017). Sakarya TÖMER'de Türkçe öğrenen yabancı öğrencilerin iyelik ve hâl eklerini ögrrenmelerinde dolayl ve doğrudan geribildirimin etkisi. Yayımlanmamış Yüksek Lisans Tezi, Sakarya Üniversitesi.

Kınay, D.E. (2017). Yabancı dil olarak Türkçe öğretiminde sosyal etkinlikler ile dil öğretimi. Hacettepe Üniversitesi Yabancı Dil Olarak Türkçe Araştırmaları Dergisi, 3: 53-75. https://dergipark.org.tr/tr/pub/huydotad/issue/37786/436243

MacDonald, M. N., Badger, R., ve Dasli, M. (2006). Authenticity, culture and language learning. Language and intercultural communication, 6(3-4), 250-261. http://hdl.handle.net/10036/41013

Mahadi, T. S. T., ve Jafari, S. M. (2012). Motivation, its types, and its impacts in language learning. International Journal of Business and Social Science, 3(24). https://ijbssnet.com/journals/Vol_3_No_24_Special_Issue_December_2012/24.pdf

Miles, M. B., ve Huberman, A. M. (1994). Qualitative data analysis: An expanded sourcebook (2. baskı). Thousand Oaks, CA: Sage.

Miles, M.B., Huberman, A.M., ve Saldana, J. (2014). Qualitative data analysis: A methods sourcebook (3rd ed.). Los Angeles: Sage.

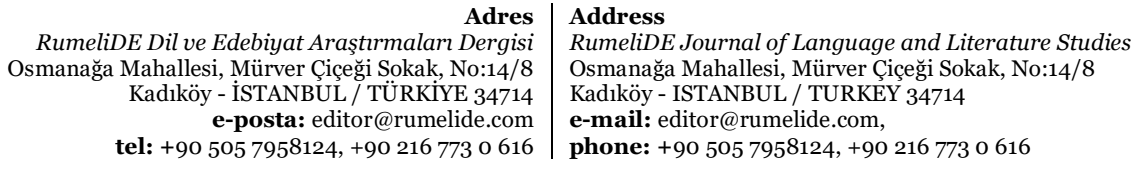


Nakata, Y. (2006). Motivation and experience in foreign language learning. Oxford, UK: Peter Lang.

Nguyen, H. T., Warren W. ve H. Fehring (2014). Factors Affecting English Language Teaching and Learning in Higher Education, English Language Teaching 7 (8). 94-105. http://dx.doi.org/10.5539/elt.v7n8p94

Ni, H. (2012). The Effects of Affective Factors in SLA and Pedagogical Implications. Theory and Practice in Language Studies, 2(7). 1508-1513. http://dx.doi.org/10.4304/tpls.2.7

Özdemir, A. , Özkan, T. , De Chiara, K. F., Demir, K. , Kara, F. ve Kınsız, M. (2014). Yabancı dil olarak Türkçe öğretiminde sosyal etkinlikler: Tiyatro örneği ve uygulamanın öğrenci performansına etkisi. Diyalog Dergisi, 2, 83-96. https://dergipark.org.tr/tr/download/article-file/441010

Özer, B. ve Korkmaz, C. (2016) Yabancı dil öğretiminde öğrenci başarısını etkileyen unsurlar. EKEV Akademi Dergisi, 20 (67), 59-84.

Sarıçoban, A. ve Çalışkan, G. (2011). The influence of target culture on language learners. Journal of Language and Linguistic Studies, 7(1). https://www.jlls.org/index.php/jlls/article/view/101

Şengül, K. (2014). Türkçenin yabancı dil olarak öğretiminde alfabe sorunu. Uluslararası Türkçe Edebiyat Kültür Eğitim (TEKE) Dergisi, 3(1), 325-339. http://www.tekedergisi.com/Makaleler/361907263_20\%C5\%9Feng\%C3\%BCl.pdf

Türkoğlu, S. (2004). Dil öğretiminde başarıyı etkileyen etmenler. Kazım Karabekir Eğitim Fakültesi Dergisi, 9. 457-469. https://dergipark.org.tr/download/article-file/31355

Yıldırım, A., ve Şimşek, H. (2018). Sosyal bilimlerde nitel araştırma yöntemleri (11. Baskı). Ankara: Seçkin.

RumeliDE Dil ve Edebiyat Araştırmaları Dergisi Osmanağa Mahallesi, Mürver Çiçeği Sokak, No:14/8 Kadıköy - İSTANBUL / TÜRKIYE 34714 e-posta: editor@rumelide.com tel: +90 $5057958124,+902167730616$
Address

RumeliDE Journal of Language and Literature Studies Osmanağa Mahallesi, Mürver Çiçeği Sokak, No:14/8

Kadıköy - ISTANBUL / TURKEY 34714

e-mail: editor@rumelide.com,

phone: +90 5057958124 , +90 2167730616 